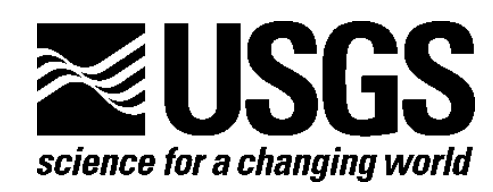

\title{
Observations of Coastal Sediment Dynamics of the Tijuana Estuary Fine Sediment Fate and Transport Demonstration Project, Imperial Beach, California
}

By Jonathan A. Warrick, Kurt Rosenberger, Angela Lam, Joanne Ferreira, lan M. Miller, Meg Rippy, Jan Svejkovsky, and Neomi Mustain

Open File Report 2012-1083

U.S. Department of the Interior

U.S. Geological Survey 


\title{
U.S. Department of the Interior \\ KEN SALAZAR, Secretary
}

\author{
U.S. Geological Survey \\ Marcia K. McNutt, Director
}

U.S. Geological Survey: Reston, Virginia: 2012

For product and ordering information:

World Wide Web: http://www.usgs.gov/pubprod

Telephone: 1-888-ASK-USGS

For more information on the USGS-the Federal source for science about the Earth, its natural and living resources, natural hazards, and the environment:

World Wide Web: http://www.usgs.gov

Telephone: 1-888-ASK-USGS

Suggested citation:

Warrick, J.A., Rosenberger, K., Lam, A., Ferreira, J., Miller, I.M., Rippy, M., Svejkovsky, J., and Mustain, N., 2012, Observations of coastal sediment dynamics of the Tijuana Estuary Fine Sediment Fate and Transport Demonstration Project, Imperial Beach, California, U.S. Geological Survey Open-File Report 2012-1083, 29 p and data files. (Available at $h$ ttp://pubs.usgs.gov/of/2012/1083/.)

Any use of trade, product, or firm names is for descriptive purposes only and does not imply endorsement by the U.S. Government.

Although this report is in the public domain, permission must be secured from the individual copyright owners to reproduce any copyrighted material contained within this report. 


\section{Contents}

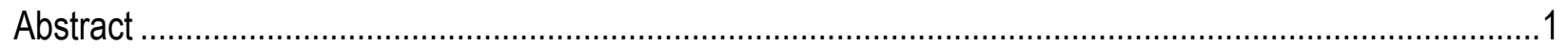

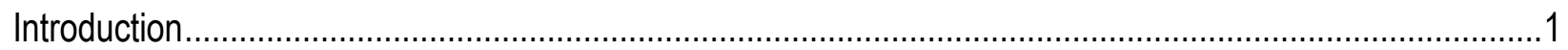

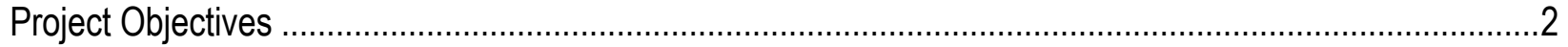

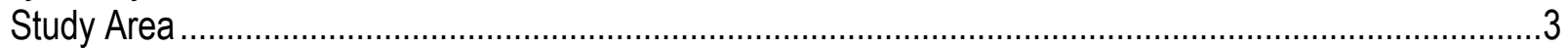

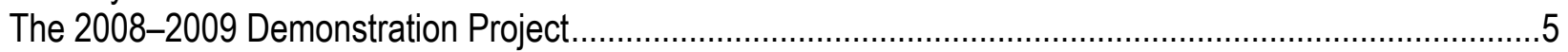

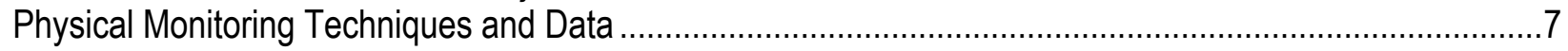

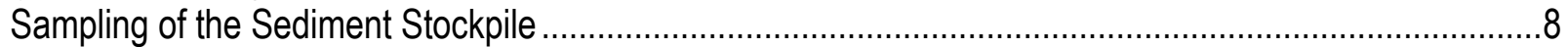

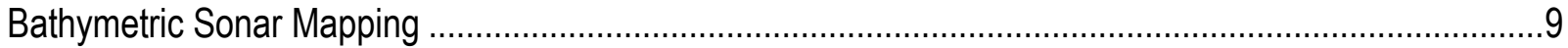

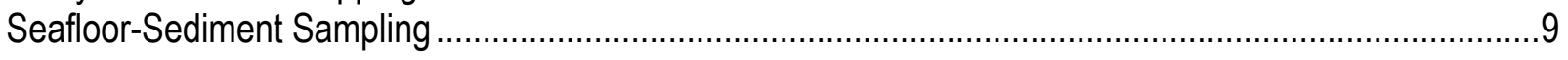

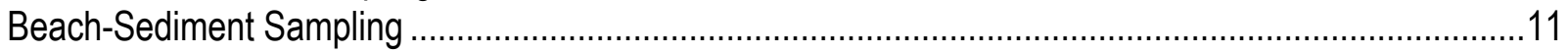

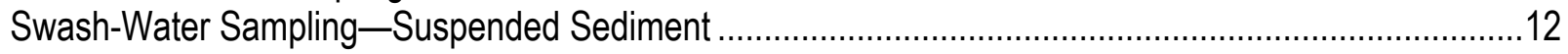

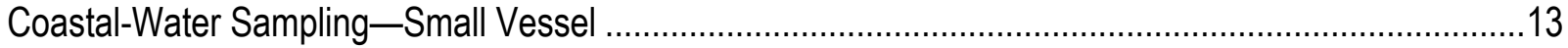

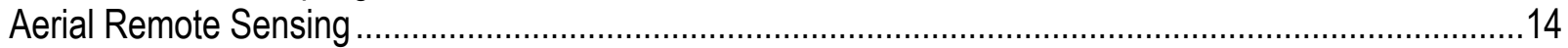

Oceanographic Observations_-Tripods and Moored Buoys ………….............................................15

Acoustic Doppler Current Profilers (ADCP and ADP) ……........................................................17

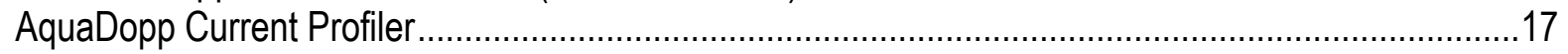

Acoustic Doppler Velocimeters (ADV) ……..........................................................................19

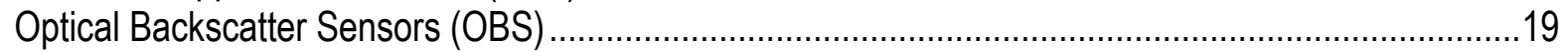

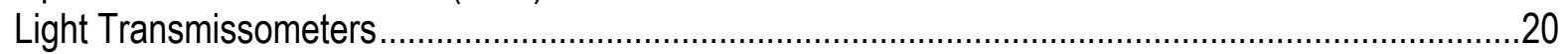

Conductivity-Temperature (CT) and Conductivity-Temperature-Depth (CTD) Recorders .....................20

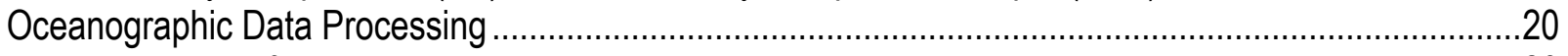

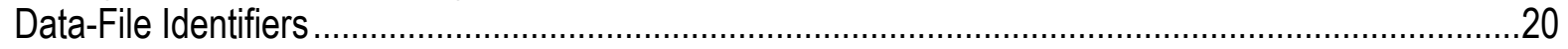

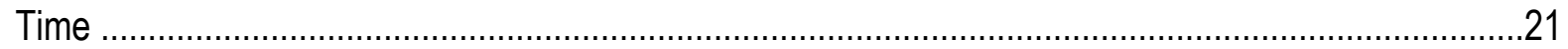

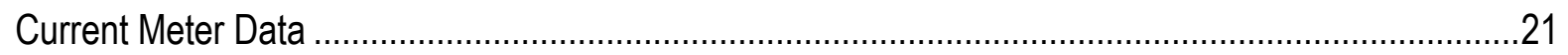

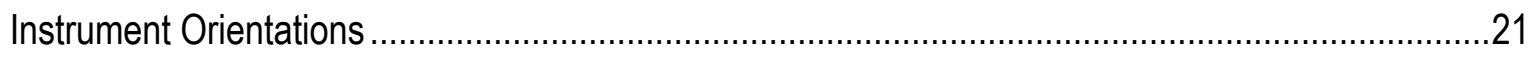

Acoustic Doppler Current Meter (ADCP) Data ......................................................................21

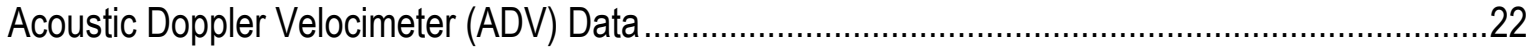

Optical Backscatter Sensor (OBS) Data ……………………………………………....22

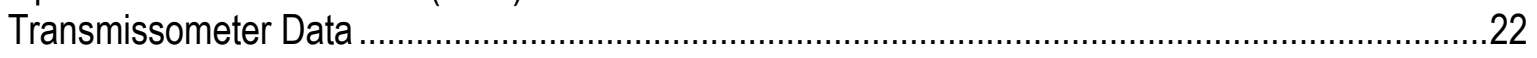

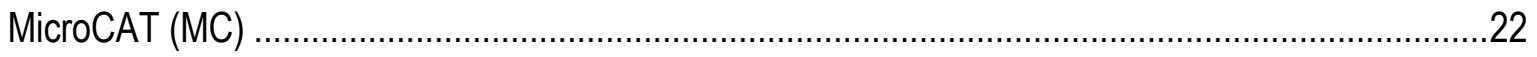

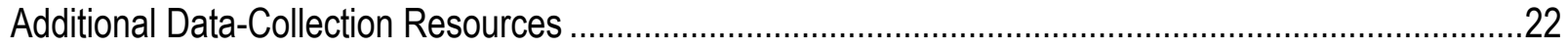

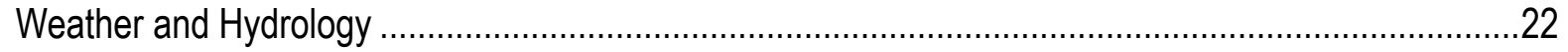

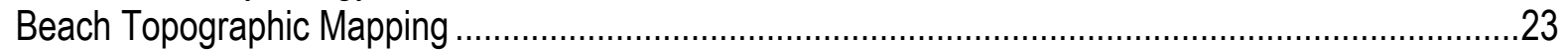

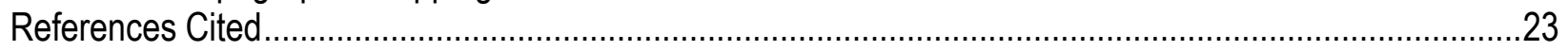

Appendix 1 - Sediment grain-size distribution data from the pre-placement stockpile................................24

Appendix 2 - Sediment grain-size distribution data from seafloor samples..............................................2

Appendix 3 - Sediment grain-size distribution data from beach samples...............................................26

Appendix 4 - Suspended-sediment concentration and grain-size distribution data from beach-

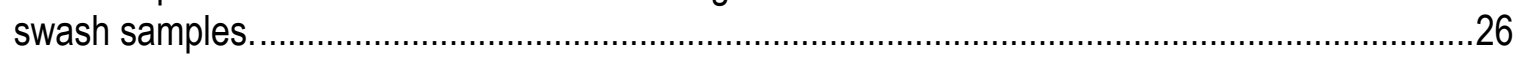

Appendix 5 - Conductivity-temperature depth (CTD) and optical turbidity measurements from small

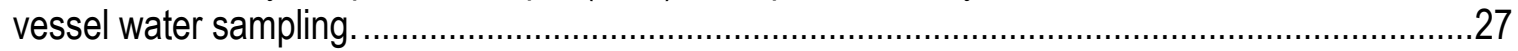

Appendix 6 - Suspended-sediment concentration measurements from small vessel water

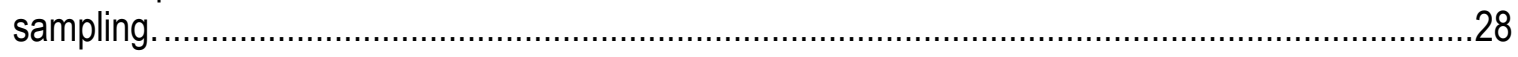

Appendix 7 - Remote-sensing imagery. ………………................................................................28

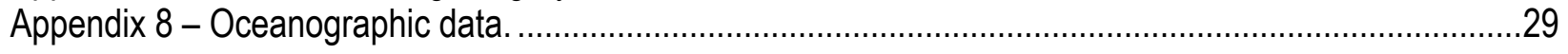




\section{Figures}

1. Map of the study area and sampling sites, Imperial Beach, California. ................................................

2. Photographs of the study site and sediment-nourishment project.........................................................5

3. Nourishment and sampling schedule during Phase I (2008) of the Demonstration Project. ...................7

4. Nourishment and sampling schedule during Phase II (2009) of the Demonstration Project. ..................8

5. Map of seafloor sediment-sampling locations during the May 2008 investigations of the study area.

6. Photograph of the conductivity-temperature-depth (CTD) instrument with the additional optical backscatterance sensor (OBS) and 25-cm pathlength transmissometer.

7. Photographs of moorings utilized in the Demonstration Project

\section{Tables}

1. Roles of project partners for the Demonstration Project

2. Sediment placement schedule for Phase I (2008) of the Demonstration Project.......................................6

3. Sediment placement schedule for Phase II (2009) of the Demonstration Project....................................6

4. Ocean sampling locations for seafloor sediment samples and water column sampling by conductivity-temperature depth (CTD) sensor.

5. Beach swash sampling locations for the Demonstration Project........................................................ 12

6. Oceanographic platform stations for Phase I (2008) of the Demonstration Project ..................................16

7. Oceanographic platform stations for Phase II (2009) of the Demonstration Project ................................17

8. Oceanographic instrumentation for the stations during Phase I (2008) of the Demonstration Project.

9. Oceanographic instrumentation for the stations during Phase II (2009) of the Demonstration

Project. 


\title{
Observations of Coastal Sediment Dynamics of the Tijuana Estuary Fine Sediment Fate and Transport Demonstration Project, Imperial Beach, California
}

By Jonathan A. Warrick ${ }^{1}$, Kurt Rosenberger ${ }^{1}$, Angela Lam ${ }^{1}$, Joanne Ferreira ${ }^{1}$, Ian M. Miller ${ }^{1,2}$, Meg Rippy ${ }^{3}$, Jan Svejkovsky ${ }^{4}$, and Neomi Mustain ${ }^{4}$

\begin{abstract}
Coastal restoration and management must address the presence, use, and transportation of fine sediment, yet little information exists on the patterns and/or processes of fine-sediment transport and deposition for these systems. To fill this information gap, a number of State of California, Federal, and private industry partners developed the Tijuana Estuary Fine Sediment Fate and Transport Demonstration Project ("Demonstration Project") with the purpose of monitoring the transport, fate, and impacts of fine sediment from beach-sediment nourishments in 2008 and 2009 near the Tijuana River estuary, Imperial Beach, California. The primary purpose of the Demonstration Project was to collect and provide information about the directions, rates, and processes of fine-sediment transport along and across a California beach and nearshore setting. To achieve these goals, the U.S. Geological Survey monitored water, beach, and seafloor properties during the 2008-2009 Demonstration Project. The project utilized sediment with $\sim 40$ percent fine sediment by mass so that the dispersal and transport of fine sediment would be easily recognizable. The purpose of this report is to present and disseminate the data collected during the physical monitoring of the Demonstration Project. These data are available online at the links noted in the "Additional Digital Information" section. Synthesis of these data and results will be provided in subsequent publications.
\end{abstract}

\section{Introduction}

Each year millions of tons of fine sediment (silt and clay) are released into the coastal waters of California from the natural erosion of the adjacent landscape. The majority of this sediment enters from coastal streams and rivers, although the failure of coastal bluffs and cliffs also may contribute significantly within certain regions (Inman and Jenkins, 1999; Farnsworth and Warrick, 2007). Fine sediment (here defined to be sediment particles with diameters less than or equal to $0.063 \mathrm{~mm}$ ) is an important constituent of these coastal systems because of its role in nutrient cycling, habitat formation, and the geological cycle; however, fine sediment also is responsible for elevating water turbidity and burying sandy or rocky benthic habitats, and fine sediment is a common vector for pollutant transport (Olson and others, 1982; Fowlera, 1990).

\footnotetext{
${ }^{1}$ U.S. Geological Survey.

3 niversity of California, Santa Cruz.

3 Scripps Institute of Oceanography.

4 Ocean Imaging Corporation.
} 
Coastal restoration and management must address the presence, use, and potential transportation of fine sediment, yet little information exists on the patterns and/or processes of fine-sediment transport and deposition for these systems. To fill this information gap, a number of State of California, Federal, and private industry partners developed the Tijuana Estuary Fine Sediment Fate and Transport Demonstration Project ("Demonstration Project") with the purpose of monitoring the transport, fate, and impacts of fine sediment from beach-sediment nourishments in 2008 and 2009 near the Tijuana River estuary, Imperial Beach, California. The lead agency of the Demonstration Project was the California Coastal Conservancy, and project funding was provided by the California Ocean Protection Council, the California Coastal Conservancy, the California Department of Boating and Waterways, the U.S. Army Corps of Engineers, and the U.S. Geological Survey (USGS). Important project support came from the Tijuana River National Estuarine Research Reserve, Southwest Wetlands Interpretive Association, California State Parks-Border Field State Park, California Sediment Management Workgroup (CSMW), Moffatt and Nichol Engineers, Nautilus Environmental, Nordby Biological Consulting, Diamond Lane Contractors, Ocean Imaging Corporation, CoastalCOMS, and Deltares. A summary of the roles and responsibilities of the project partners is included in table 1 .

Table 1. Roles of project partners for the Demonstration Project.

\begin{tabular}{|l|l|}
\hline \multicolumn{1}{|c|}{ Role } & \multicolumn{1}{|c|}{ Project Partner (contact) } \\
\hline Project Manager & $\begin{array}{l}\text { California Coastal Conservancy (Karen Bane) } \\
\text { Border Field State Park (Clay Parks) }\end{array}$ \\
\hline Project environmental permitting & $\begin{array}{l}\text { Border Field State Park (Chris Peregrin) } \\
\text { Moffet \& Nichols (Brian Leslie) }\end{array}$ \\
\hline Pre-project sediment sampling and analysis & $\begin{array}{l}\text { Moffet \& Nichols (Brian Leslie) } \\
\text { AMEC Earth \& Environmental (Nick Buhbe) }\end{array}$ \\
\hline Physical monitoring study design and implementation & $\begin{array}{l}\text { U.S. Geological Survey (Jonathan Warrick) } \\
\text { Univ. of California, Santa Cruz (Ian Miller) }\end{array}$ \\
& $\begin{array}{l}\text { Scripps Institue of Oceanography (Meg Rippy) } \\
\text { Ocean Imaging Corporation (Jan Svejkovsky) } \\
\text { CoastalCOMS (Dave Revell) }\end{array}$ \\
\hline Numerical modeling of sediment tranport & Deltares (Jamie Lescinski) \\
\hline Biological monitoring study design and Implementation & Nautilus Environmental (Nick Buhbe) \\
\hline Sediment excavation, sorting and placement & Diamond Lane Contractors (Mike Adams) \\
\hline Sediment placement management & Nordby Consulting (Chris Norby) \\
\hline Project Funding & $\begin{array}{l}\text { California Ocean Protection Council } \\
\text { California Coastal Conservancy }\end{array}$ \\
California Department of Boating and Waterways \\
U.S. Army Corps of Engineers \\
U.S. Geological Survey
\end{tabular}

The purpose of this report is to present the data collected during the physical monitoring plan of the Demonstration Project. The USGS was the lead agency for this data collection, and assistance and partnering was provided by Ocean Imaging Corporation; the University of California, Santa Cruz; and Scripps Institute of Oceanography. Data are presented below in sections organized by the project schedule and sampling methods. These data are available online at the links noted in the "Additional Digital Information" section.

\section{Project Objectives}

The purpose of the Demonstration Project was to collect and provide information about the directions, rates, and processes of fine-sediment transport along and across a California beach 
and nearshore setting. A better understanding of fine-sediment transport and fate is necessary to protect and enhance marine resources and better manage and regulate sediment resources along the California coastline. Little information exists about the transport and fate of fine sediment in these coastal settings; thus, a primary goal of the Demonstration Project was to collect physical information about the rates, pathways, and fate of fine sediment. The second goal of the Demonstration Project was to use these physical data to develop a process-based understanding and mass balance of fine-sediment transport and deposition so that the results of this work could be more broadly applied to other physical settings. Although this second goal was critical for the proper application of the results of the Demonstration Project, it is not a primary goal of this report but will be addressed in subsequent publications.

To achieve these goals, scientists monitored the water, beach, and seafloor properties near a beach-nourishment project adjacent to the Tijuana River estuary. This nourishment project utilized sediment with substantial levels ( $\sim 40$ percent by mass) of fine sediment so that the dispersal and transport of fine sediment would be easily recognizable. The project consisted of two beach nourishments - one in 2008 and the other in 2009-during which several tens of thousands of cubic meters of sediment were placed directly into the surf zone at the Border Field State Park beach. Monitoring included airborne remote sensing, beach-water and sediment sampling, nearshore water-column and seafloor sampling from small boats, and oceanographic sampling from moored stations. These observations revealed the spatial and temporal patterns of turbidity and sedimentation associated with the nourishment project's fine sediment and how environmental conditions (waves, winds, and ocean currents) influenced these patterns.

\section{Study Area}

The study site for the Demonstration Project is the southern beach of the Tijuana River National Estuarine Research Reserve and Border Field State Park of southern California (fig. 1). Substantial wetland loss in the southern Tijuana River estauary has occurred during the past few decades owing to sedimentation resulting from sediment discharge from the increased urbanization of tributaries within Mexico. To help alleviate this problem, two debris basins, which annually trap approximately $30,000 \mathrm{~m}^{3}$ of sediment, were built at the mouth of the largest tributary, Goat Canyon. This sediment is expensive for the State Park to remove and dispose of, and it could provide beneficial reuse as a supply for beach nourishment. This sediment also contains a high percentage (approximatlely 40 percent) of fine sediment (silt and clay), and therefore it would not be considered suitable for beach nourishment under present-day regulations.

The beach of the project site is part of the greater Silver Strand littoral cell, which extends north to the Coroado Peninsula and south past the United States-Mexico international border (Inman, 1976; Kuhn and Shepard, 1984; Flick, 1993). The beaches of this littoral cell are primarily sandy, and although the primary source of this beach sand is the Tijuana River, there have been numerous sand-nourishment projects in this littoral cell to attempt to limit, stop, or reverse coastal erosion (Flick, 1993; San Diego Association of Governments, 2012). 


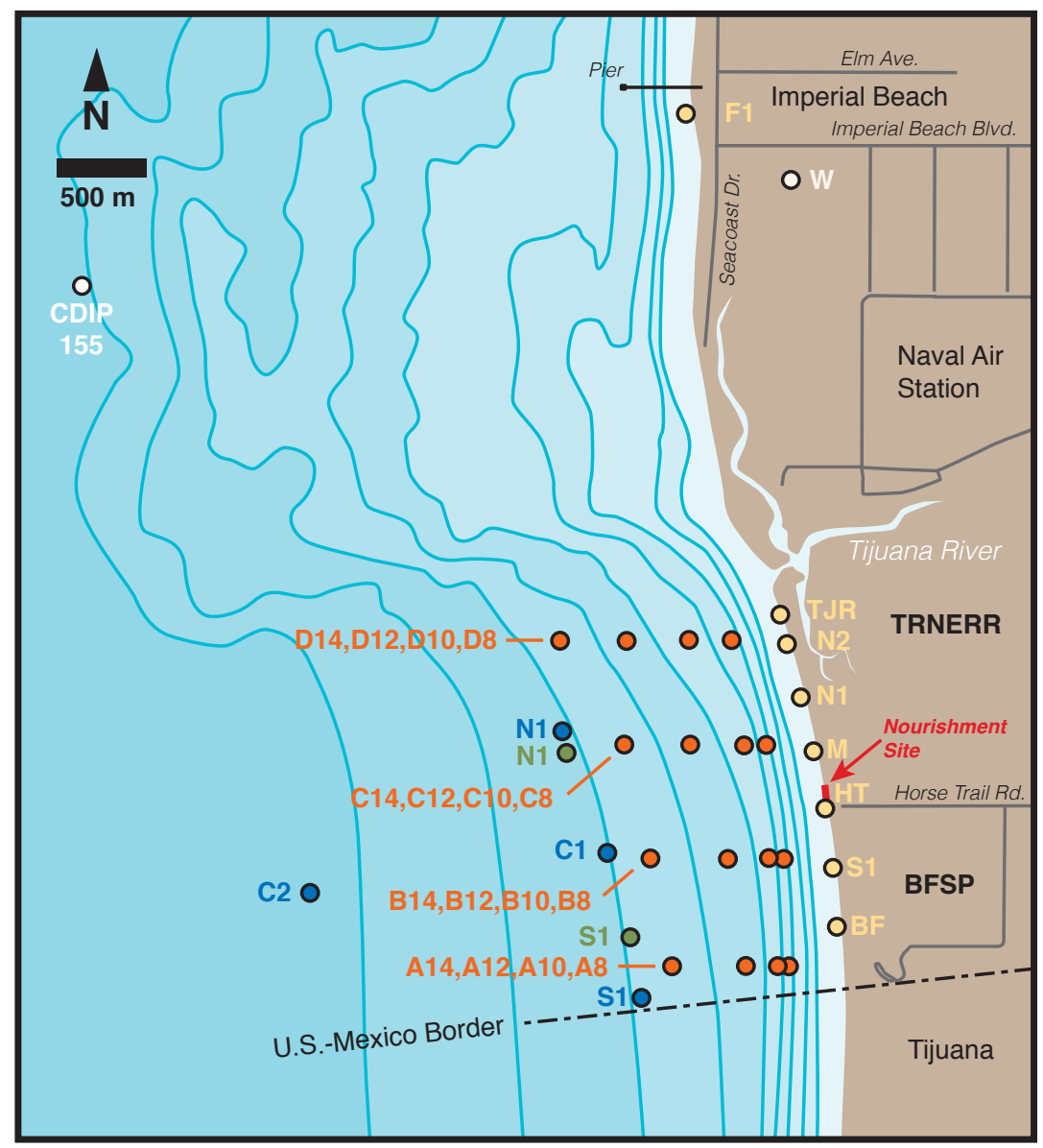

Figure 1. Map of the study area and sampling sites, Imperial Beach, California. Sites are color coded for swash sampling (yellow), nearshore small boat sampling (orange), buoy and tripod sampling (blue, Phase I; green, Phase II), and weather station (white). Coastal bathymetry (blue lines) shown at $2 \mathrm{~m}$ increments from -3 to $-19 \mathrm{~m}$. The locations of the Tijuana River National Estuarine Research Reserve (TJNERR) and the Border Field State Park (BFSP) also are shown.

Bisecting the study area beach is the Tijuana River mouth, which serves as the inlet of tidal exchange between the ocean and the Tijuana River estuary and as the outlet for Tijuana River discharge (Zedler and others, 1992; fig. 1). The mouth of the Tijuana River is rarely closed, resulting in regular tidal pumping and exchange of water and sediment through the river mouth. The river discharges elevated rates of water, sediment, and pollutants after winter rainfall events (Svejkovsky and others, 2010). Using 46 years of historical data, Farnsworth and Warrick (2007) calculated that the Tijuana River annually discharges approximately $90,000 \mathrm{~m}^{3}$ of suspended sediment to the Pacific Ocean, roughly $70,000 \mathrm{~m}^{3}$ - or 77 percent — of this river sediment being fine-grained (less than $0.063 \mathrm{~mm}$ ). The annual discharge of sediment from the Tijuana River is highly variable, however, ranging from 0 to $\sim 2,000,000 \mathrm{~m}^{3}$ over the historical record. Tijuana River sediment represents roughly 18 percent of the total fine sediment input into the Pacific Ocean — combined river discharge and cliff erosion-from the Peninsular Range of California (San Diego County to southern Orange County; Farnsworth and Warrick, 2007). 


\section{The 2008-2009 Demonstration Project}

The goal of the Demonstration Project was to monitor the transport and fate of fine sediment placed on the beach, and a number of activities were required to get the sediment from the debris basins to the shoreline. These activities included: (1) environmental permitting of the project, (2) excavation of sediment from the debris basins, (3) stockpiling the sediment on the processing pad, (4) sorting the sediment for trash and debris, (5) testing the sediment for grain size and environmental contaminants, and (6) hauling and placement of sediment on the beach. Although steps (1) to (5) were lengthy and critical elements to the success of this project, the focus of this report is on the hauling and placement routine and schedule. Project partners that managed other elements of the Demonstration Project are listed in table 1.

Once dry sediment was acquired from the sediment basins and trash and debris (including gravel-sized sediment) were sorted out, the sediment was stockpiled on a processing pad roughly $1.5 \mathrm{~km}$ from the beach. During sediment placement operations, dump trucks were filled with sorted sediment and driven down Horse Trail Road to the beach, where the sediment was placed in the intertidal zone immediately north of the road's end (fig. 2). There were two styles of placement utilized during the Demonstration Project. The first placement style consisited of opening up the dump truck bay while driving through the intertidal swash zone (fig. 2b). This technique produced an elongated strip of sediment that was rapidly suspended into the swash. The second technique consisted of backing the trucks into the intertidal zone and dumping sediment in large piles. Sediment placed using this technique remained in piles for minutes to hours, depending on placement location and wave energy in the swath (fig. 2c). The sediment was not manipulated after being placed on the beach.

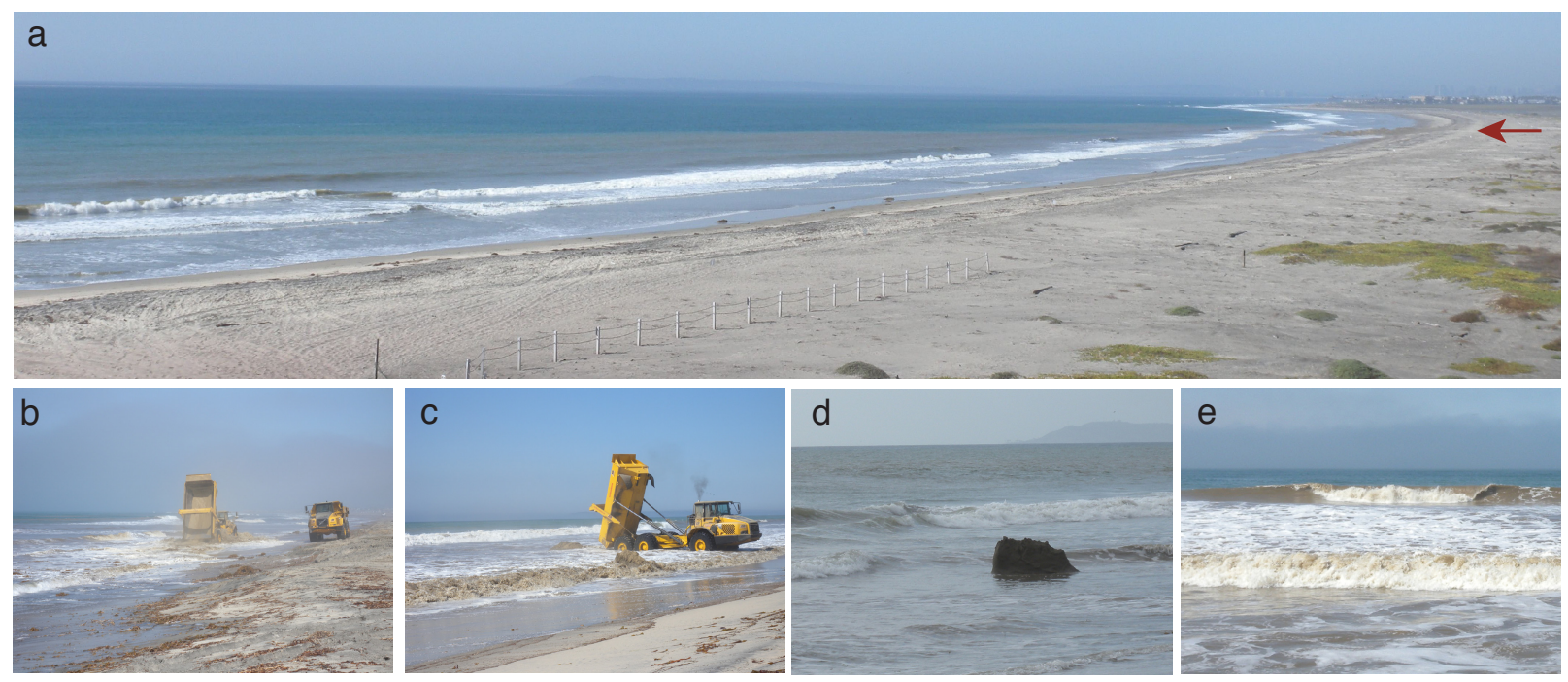

Figure 2. Photographs of the study site and sediment-nourishment project. (a) Overview perspective from the United States-Mexico border showing the sediment placement site (arrow) and southern-directed turbid plume on October 1, 2009,1447 PDT. (b and c) Sediment placement within the swash zone. (d) A recently placed pile of sediment in the swash. (e) Turbid surf zone immediately adjacent to the sediment placement site.

There were two sediment placements - one in 2008 (Phase I) and the other in 2009 (Phase II) - and schedules for each are given in tables 2 and 3 and shown graphically in figures 3 and 4 . The volumetric estimates were made by using daily counts of truck deliveries; each truck 
carried approximately $19 \mathrm{~m}^{3}$. The 2008 Phase I placement consisted of 7,600 $\mathrm{m}^{3}$ of sediment placed during an interval of 10 days. This intial placement was hampered by rain on November 6-8, 2008, which slowed operations and led to the eventual failure of Horse Trail Road during the afternoon of November 6th. The road was repaired temporarally and placement activities were resumed, allowing for intermittment sediment placement during November 10-13. Phase I of the project was discontinued after $7,600 \mathrm{~m}^{3}$ of sediment was placed on the beach (table 2). Phase II could not begin until significant improvements were made to Horse Trail Road. After reconstruction of the road in the summer of 2009, Phase II of the Demonstration Project was initiated on September 21, 2009, and finished on October 2, 2009. During Phase II, 26,800 $\mathrm{m}^{3}$ of sediment was placed during a 12-day interval (table 3 ).

Table 2. Sediment placement schedule for Phase I (2008) of the Demonstration Project.

\begin{tabular}{|l|l|l|l|l|}
\hline \multicolumn{1}{|c|}{ Date } & $\begin{array}{c}\text { Start Time } \\
\text { (PDT) }\end{array}$ & $\begin{array}{c}\text { End Time } \\
(\text { PDT) }\end{array}$ & $\begin{array}{c}\text { Placement } \\
\left.\text { volume } \mathbf{~ ( m}^{3}\right)\end{array}$ & \multicolumn{1}{|c|}{ Notes } \\
\hline 03 Nov 2008 & $10: 15$ & $10: 30$ & 12 & Initial testing of technique and roads. \\
\hline 04 Nov 2008 & & & 1910 & First full day of sediment placement \\
\hline 05 Nov 2008 & & & $\sim 1000$ & Road to beach fails at midday \\
\hline 06 Nov 2008 & & & & No placement - road repair \\
\hline 07 Nov 2008 & & & & No placement - road repair \\
\hline 08 Nov 2008 & & & & No placement - road repair \\
\hline 09 Nov 2008 & & & $\sim 2000$ & No placement - road repair \\
\hline 10 Nov 2008 & & & & No placement \\
\hline 11 Nov 2008 & & & 1910 & \\
\hline 12 Nov 2008 & & & 760 & \\
\hline 13 Nov 2008 & & & & \\
\hline
\end{tabular}

Table 3. Sediment placement schedule for Phase II (2009) of the Demonstration Project.

\begin{tabular}{|c|c|c|c|c|}
\hline Date & $\begin{array}{c}\text { Start Time } \\
\text { (PDT) }\end{array}$ & $\begin{array}{l}\text { End Time } \\
\text { (PDT) }\end{array}$ & $\begin{array}{c}\text { Placement } \\
\text { volume }\left(\mathrm{m}^{3}\right)\end{array}$ & Notes \\
\hline 21 Sept 2009 & $7: 40$ & $17: 00$ & 2980 & \\
\hline 22 Sept 2009 & $7: 15$ & $16: 40$ & 3150 & \\
\hline 23 Sept 2009 & $7: 00$ & $16: 40$ & 2700 & \\
\hline 24 Sept 2009 & $7: 00$ & $16: 40$ & 3300 & \\
\hline 25 Sept 2009 & 7:00 & $16: 40$ & 3920 & \\
\hline 26 Sept 2009 & & & & No placement - weekend \\
\hline 27 Sept 2009 & & & & No placement - weekend \\
\hline 28 Sept 2009 & 7:00 & $16: 40$ & 3490 & \\
\hline 29 Sept 2009 & 7:00 & 13:00 & 1710 & Placement ended early \\
\hline 30 Sept 2009 & & & & No placement \\
\hline 01 Oct 2009 & 7:00 & $16: 15$ & 4000 & \\
\hline 02 Oct 2009 & 7:00 & 13:00 & 1520 & \\
\hline
\end{tabular}



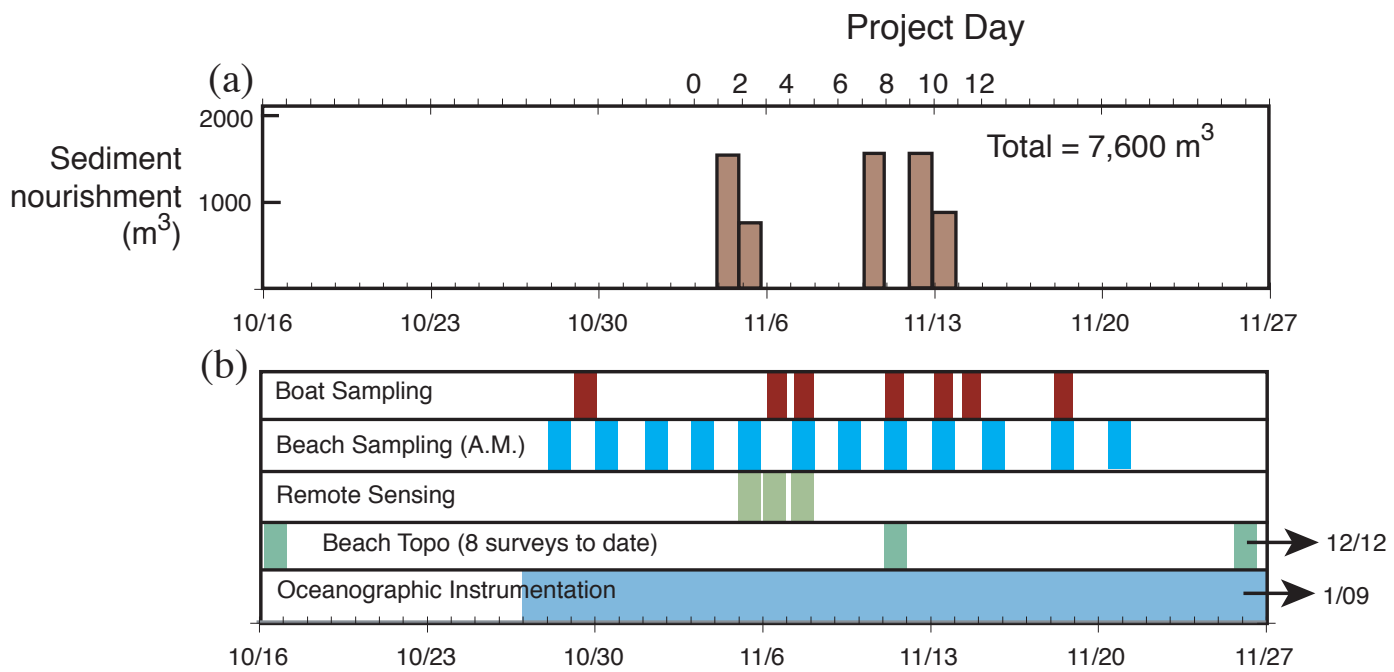

(c)

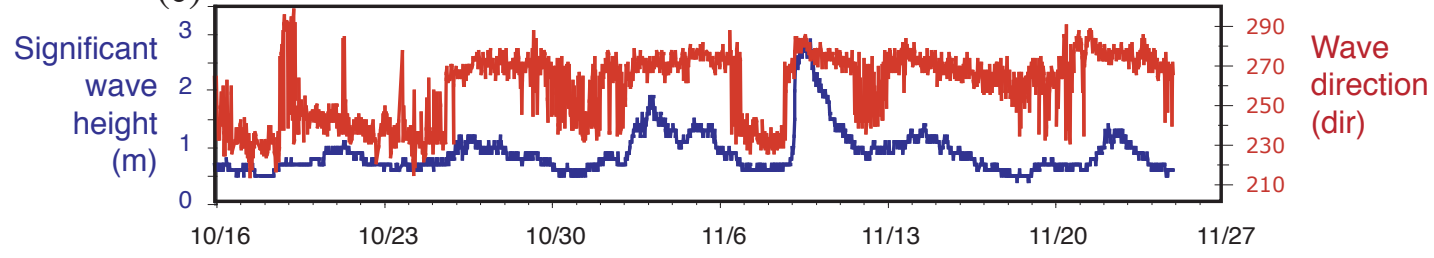

Figure 3. Nourishment and sampling schedule during Phase I (2008) of the Demonstration Project. (a) Sediment-nourishment schedule in total placement per day. (b) Sampling schedule from the various monitoring methods (see text for details). (c) Significant wave height and dominant wave direction from Coastal Data Information Program (CDIP) buoy 155.

\section{Physical Monitoring Techniques and Data}

An integrated monitoring program was developed to examine the physical transport and fate of fine sediment placed in the nearshore for the Demonstration Project. The primary research questions addressed in this program were:

1. What are the patterns, residence times, and mechanisms of water turbidity due to the introduced fine sediment?

2. What are the patterns, residence times, and mechanisms of sedimentation on the seafloor due to the introduced fine sediment?

3. What are the sediment-transport pathways that lead to the final sink for the fine sediment?

4. How does project implementation (volume and mechanism of placement) influence sediment transport and fate? 


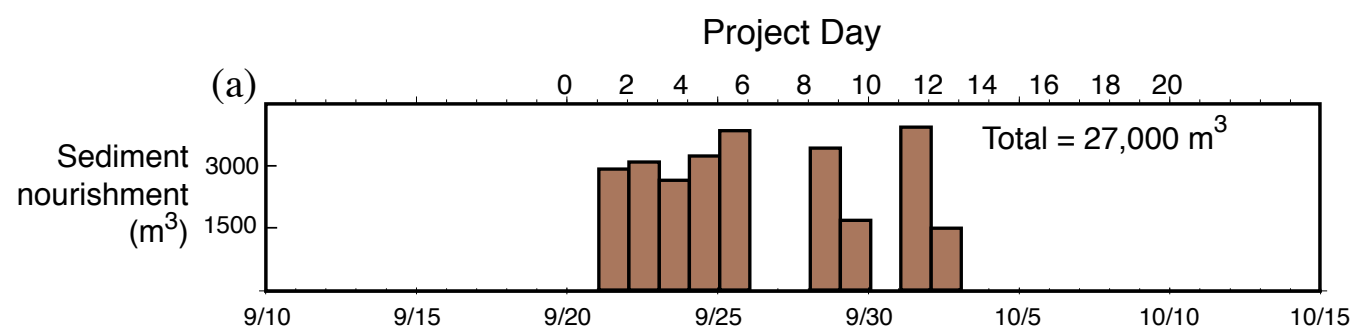

(b)

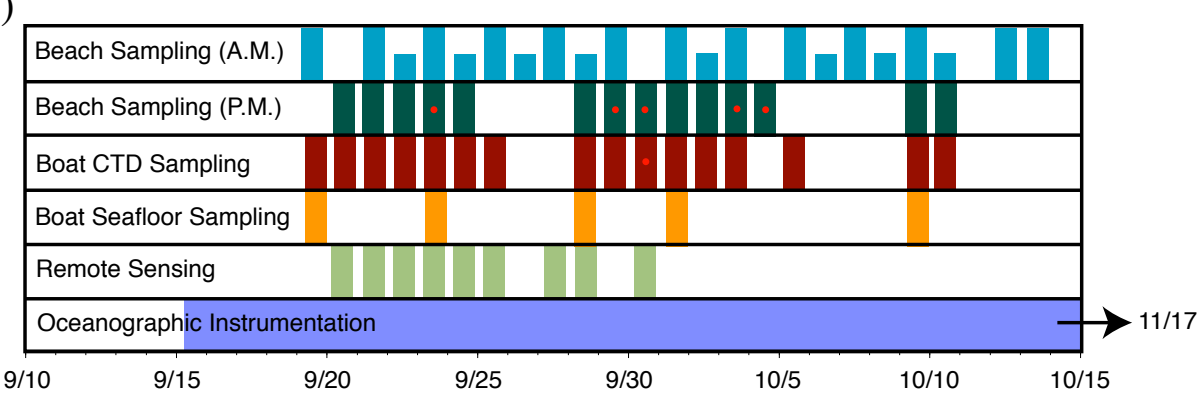

(c)

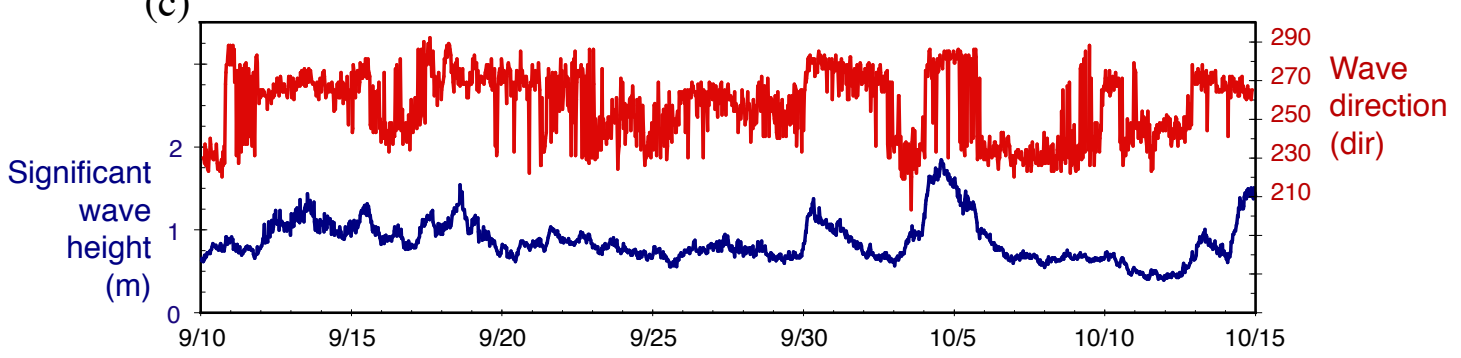

Figure 4. Nourishment and sampling schedule during Phase II (2009) of the Demonstration Project. (a) Sediment nourishment schedule in total placement per day. (b) Sampling schedule from the various monitoring methods (see text for details). (c) Significant wave height and dominant wave direction from Coastal Data Information Program (CDIP) buoy 155.

The physical monitoring program consisted of four major stages: (1) pre-project, (2) Phase I, (3) Phase II, and (4) post-project. Several monitoring and analysis techniques were used for each stage, and a description of these techniques are provided below. A summary of the schedule for these monitoring activities is shown in figures 3 and 4. Data from these monitoring activities are provided in the appendixes of this report.

\section{Sampling of the Sediment Stockpile}

Although sampling and description of the stockpiled sediment was done by Moffet and Nichols and AMEC Earth and Environmental for pre-project permitting, additional samples of the stockpiled sediment were obtained to evaluate grain-size distributions by using techniques identical to those utilized for the remainder of the physical monitoring. On May 15, 2009, Chris Peregrin, Environmental Coordinator of the Border Field Station State Park, collected three 1-kg samples of the stockpiled sediment. Samples were obtained by removing $10 \mathrm{~cm}$ of the surface of the sediment stockpile to eliminate sample biasing from wind winnowing of the fines and sampling with a small spade. 
All samples were analyzed for grain-size distributions at the USGS Coastal and Marine Geology Sediment Laboratory in Menlo Park, California, using the techniques detailed in the "Seafloor Sediment Sampling" section. The results of these analyses are provided in appendix 1.

\section{Bathymetric Sonar Mapping}

During the pre-project monitoring, the bathymetry and seafloor characteristics of the nearshore region of the study area were mapped using swath sonar technology from the R/V Parke Snavely. During May 2008, approximately $14 \mathrm{~km}^{2}$ of seafloor was mapped with a 234.5kHz SEA (Systems Engineering and Assessment, Ltd.) SWATHplus-M phase-differencing sidescan sonar. Real-time kinematic (RTK) GPS position data were passed through a CodaOctopus F180 inertial measurement unit (IMU) to the sonar hardware and data-collection software.

Two seafloor products are generated by swath sonar mapping: bathymetry and acoustic backscatter. Acoustic backscatter of the seafloor is related to the general hardness properties of the seafloor; bedrock and very coarse sediment (gravel) generally have high acoustic backscatter, while sand and mud have lower backscatter. Final data from the USGS sonar mapping will be available in a forthcoming USGS Open-File Report.

\section{Seafloor-Sediment Sampling}

Seafloor-sediment samples were taken before, during, and after both phases of the Demonstration Project to track changes in the grain-size distribution of the seafloor surface. Samples were obtained by using a small (6-inch) Ponar Type grab sampler. The sampler was dropped to the seafloor on isobath contours and at regular spaced transects as described. For each grab sample, a subsample of the sediment surface 2-3 cm deep was obtained from the upper surface of the sediment in the sampler.

Two sampling grids were used during this study. First, during the pre-project monitoring of May 2008, seafloor samples were collected along several across-shore transects at regular 2-m depth intervals from 6 to $24 \mathrm{~m}$ water depths (fig. 5). Samples also were taken at numerous "targeted" sites, which were chosen from the unique or defining features observed in the sonar bathymetry backscatter results from the swath mapping (fig. 5). It was not possible to sample the seafloor within dense kelp beds, owing to limited accessability for the vessel. Second, during Phase II, seafloor samples were collected along four across-shore transects (labeled A through D) at regular 2-m depth intervals from 8 to $14 \mathrm{~m}$ water depth (fig. 1; table 4). Additionally, samples were taken adjacent to the tripods and buoys during Phase II of the project. These sites also were used for water-sampling stations as discussed below. No seafloor samples were taken during Phase I of the project owing to a failed attempt to use the underwater camera technologies (Rubin and others, 2007) to measure grain size at these sites. 


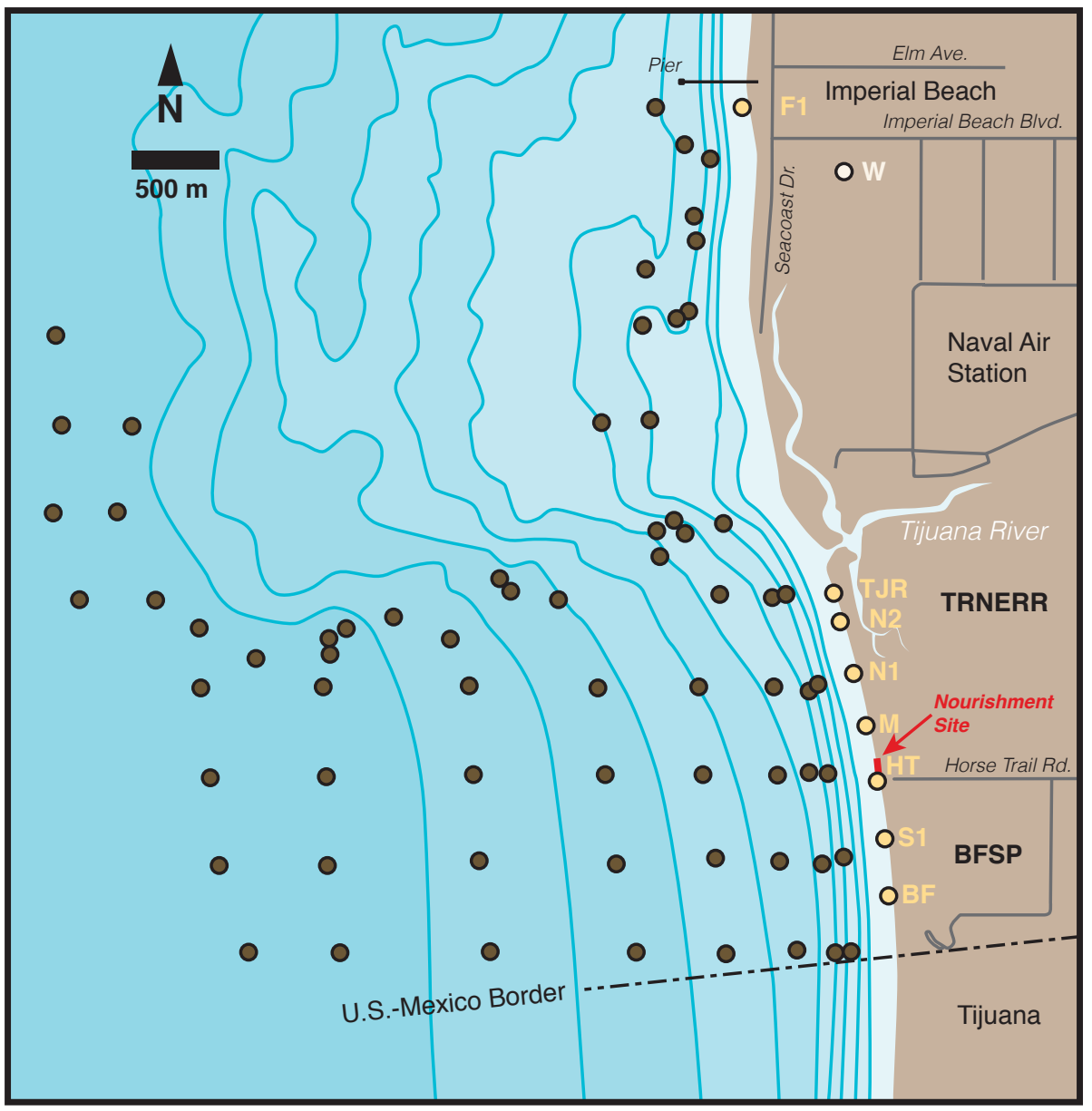

Figure 5. Map of seafloor sediment-sampling locations during the May 2008 investigations of the study area.

All samples were analyzed for grain-size distributions at the USGS Pacific Coastal and Marine Geology Science Center (PCMSC) Sediment Laboratory in Menlo Park, California, according to procedures standardized by the lab. Approximately 25 grams of homogenized sample was placed into 1,000-mL beakers with $300 \mathrm{~mL}$ of deionized (DI) water and $10 \mathrm{~mL}$ of 35-percent hydrogen peroxide overnight to digest organics. Samples were heated to drive off excess hydrogen peroxide and then placed in an ultrasonic bath for 10 minutes to disperse the silt- and clay-size sediments. Subsequently, the samples were washed twice with DI water by centrifugation for 1 hour and for 30 minutes, respectively, to remove solubles. The samples were then wet-sieved though 2-mm and 63- $\mu \mathrm{m}$ sieves to isolate the gravel (greater than $2 \mathrm{~mm}$ ), sand (63 $\mu \mathrm{m}$ to $2 \mathrm{~mm}$ ), and mud (less than $63 \mu \mathrm{m}$ ) sediment fractions. The gravel and sand fractions were collected and dried in evaporating dishes and then weighed. The mud fraction was collected in a 1,000-mL graduated cylinder, and $5 \mathrm{~mL}$ of the dispersant "calgon" (sodium hexametaphosphate) was added to the suspension to facilitate dispersal of the silt and clay. A 20$\mathrm{mL}$ aliquot of the mud suspension was taken from the graduated cylinder, dried, and weighed. The total weight of the mud fraction was determined by multiplying the $20-\mathrm{mL}$ aliquot weight by a factor of 50, owing to the 50 -fold dilution of this sediment mass (that is, $1,000 \mathrm{~mL} \div 20 \mathrm{ml}=50$ ). 
Table 4. Ocean sampling locations for seafloor sediment samples and water column sampling by CTD.

\begin{tabular}{|l|l|l|l|}
\hline \multicolumn{1}{|c|}{ Station Name } & \multicolumn{1}{|c|}{$\begin{array}{c}\text { Water Depth } \\
(\mathrm{m})\end{array}$} & \multicolumn{1}{c|}{$\begin{array}{c}\text { Latitude } \\
\text { (decimal degrees) }\end{array}$} & \multicolumn{1}{c|}{$\begin{array}{c}\text { Longitude } \\
\text { (decimal degrees) }\end{array}$} \\
\hline A08 & 8 & 32.536100 & -117.127200 \\
\hline A10 & 10 & 32.536100 & -117.128100 \\
\hline A12 & 12 & 32.536100 & -117.130600 \\
\hline A14 & 14 & 32.536100 & -117.134700 \\
\hline B08 & 8 & 32.541700 & -117.127800 \\
\hline B10 & 10 & 32.541700 & -117.128900 \\
\hline B12 & 12 & 32.541700 & -117.131700 \\
\hline B14 & 14 & 32.541700 & -117.135600 \\
\hline C08 & 8 & 32.547200 & -117.128900 \\
\hline C10 & 10 & 32.547200 & -117.130600 \\
\hline C12 & 12 & 32.547200 & -117.134200 \\
\hline C14 & 14 & 32.547200 & -117.138100 \\
\hline D08 & 8 & 32.552800 & -117.131700 \\
\hline D10 & 10 & 32.552800 & -117.134400 \\
\hline D12 & 12 & 32.552800 & -117.137800 \\
\hline D14 & 14 & 32.552800 & -117.141700 \\
\hline Buoy15 & 15 & 32.542600 & -117.139500 \\
\hline Buoy20 & 20 & 32.540700 & -117.157000 \\
\hline TRBM-N & 15 & 32.548600 & -117.142000 \\
\hline TRBM-S & 15 & 32.534900 & -117.136800 \\
\hline N15 & 15 & 32.548050 & -117.141917 \\
\hline S15 & 15 & 32.538400 & -117.137833 \\
\hline
\end{tabular}

${ }^{1}$ - Stations Buoy15, Buoy20, TRBM-N, and TRBM-S were sampled only during 2008 (Phase I) of the Demonstration Project.

2 - Stations N15 and S15 were sampled only during 2009 (Phase II) of the Demonstration Project.

Particle-size distribution was determined by using a Beckman Coulter LS230 laser diffraction particle-size analyzer. The sample's sand and mud fractions were processed separately, and these data were merged and integrated together using the mass concentration of sand and mud. Results of the seafloor sampling are provided in appendix 2.

\section{Beach-Sediment Sampling}

Sediment of the foreshore of the study area beach was sampled and analyzed for grainsize distributions to evaluate the potential influence of the Demonstration Project sediment on the native beach sand. Two sampling techniques were utilized for beach sediment. First, surface grab samples of the upper $2-3 \mathrm{~cm}$ of beach sand were obtained using a small spoon. Twenty-one beach samples were taken in May 2008 during the pre-project phase. Additional beach surface samples were obtained before, during, and after the sediment placement during Phase II of the Demonstration Project at the swash-water sampling stations (fig. 1; table 5). For each sampling station, three samples were obtained, each at a different elevation on the beach shoreface. "Upper" beach samples were obtained approximately $10 \mathrm{~cm}$ downslope of the uppermost swash line from the previous high tide; "mid-beach" samples were obtained at the upper limit of the wetted swash caused by the active swash on the beach at the time of sampling; and "lower" beach samples were taken in the middle of the swash zone at the time of sampling. 
Table 5. Beach swash sampling locations for the Demonstration Project.

\begin{tabular}{|l|l|l|l|}
\hline \multicolumn{1}{|c|}{ Station Name } & \multicolumn{1}{|c|}{$\begin{array}{c}\text { Location Description } \\
\mathrm{F}^{2}\end{array}$} & $\begin{array}{c}\text { Latitude } \\
\text { (decimal degrees) }\end{array}$ & \multicolumn{1}{c|}{$\begin{array}{c}\text { Longitude } \\
\text { (decimal degrees) }\end{array}$} \\
\hline $\mathrm{TJR}^{3}$ & $\begin{array}{l}\text { Imperial Beach, 50 m } \\
\text { south of municipal pier. }\end{array}$ & 32.578228 & -117.133486 \\
& $\begin{array}{l}\text { Beach immediately south } \\
\text { of the Tijuana River } \\
\text { mouth. }\end{array}$ & $\begin{array}{l}2008: 32.554300 \\
2009: 32.552950\end{array}$ & $\begin{array}{l}2008:-117.127850 \\
2009:-117.127667\end{array}$ \\
\hline $\mathrm{N} 2$ & $\begin{array}{l}\text { Between Horse Trail Rd. } \\
\text { and Tijuana River mouth. }\end{array}$ & 32.551617 & -117.127317 \\
\hline $\mathrm{N} 1$ & $\begin{array}{l}\text { Between Horse Trail Rd. } \\
\text { and Tijuana River mouth. }\end{array}$ & 32.548917 & -117.126500 \\
\hline $\mathrm{M}$ & $\begin{array}{l}\text { The middle of the State } \\
\text { Park beach. }\end{array}$ & 32.546217 & -117.125700 \\
\hline $\mathrm{HT}$ & $\begin{array}{l}\text { At terminus of Horse Trail } \\
\text { Road }\end{array}$ & 32.543333 & -117.125033 \\
\hline $\mathrm{S} 1$ & $\begin{array}{l}\text { Between Horse Trail Rd. } \\
\text { and the U.S.-Mexico } \\
\text { border fence. }\end{array}$ & 32.540367 & -117.124533 \\
\hline $\mathrm{BF}$ & $\begin{array}{l}\text { 200 m north of the U.S.- } \\
\text { Mexico border fence. }\end{array}$ & 32.537383 & -117.124267 \\
\hline
\end{tabular}

${ }^{1}$ - These sample locations correspond to the approximate crest of the beach berm. Water samples were obtained immediately downslope (westward) of these locations in ankle to knee $(20-30 \mathrm{~cm})$ water depths of the beach swash.

2 - Station F1 was sampled only during 2009 (Phase II) of the Demonstration Project.

${ }^{3}$ - The location of this station was moved southward between 2008 and 2009 owing to a lateral shift of the river mouth during the winter of 2008-'09.

The second sampling technique consisted of surface and subsurface samples collected to characterize the sediment grain-size distributions remaining on and within the beach during the post-project stage. This sampling was done only following the completion of Phase II. For subsurface sampling, pits were dug (approximately $30 \mathrm{~cm}$ by $30 \mathrm{~cm}$ ) at several locations within and nearby the sediment-nourishment site, and a 20 -m-long trench was dug across the beach face to evaluate the cross-shore patterns in sediment grain size. The location of these sites was recorded with handheld Garmin GPSmap 76CSx GPS with reported accuracy of $\pm 2 \mathrm{~m}$. The pits and trench were subsampled by using a spoon along cleaned vertical faces at several depths. All beach samples were processed for grain-size distributions at the USGS PCMSC Sediment Laboratory in Menlo Park, California, using the techniques detailed in the "Seafloor-Sampling" section. Results of the beach-sediment sampling are provided in appendix 3 .

\section{Swash-Water Sampling-Suspended Sediment}

Samples of the beach swash water were obtained before, during, and after the two project phases for analysis of suspended-sediment concentration and grain-size distribution. Swash samples were obtained using techniques consistent with swash-bacteria sampling (for example, Noble and $\mathrm{Xu}, 2004)$, which consists of dipping $250-\mathrm{mL}$ sample bottles under the water surface at "ankle depth" (approximately 10-20 cm water depth) immediately following the passage of a wave bore. Bottles were not overfilled (sample volumes were 100-200 mL) and were obtained in duplicate so that concentration and grain-size analyses could be run on separate samples. Swashwater samples were obtained from the beach-swash sampling site shown in table 5 and figure 1 . Beach-water sampling typically consisted of an early morning sampling before the initial 
sediment placement to characterize residual suspended-sediment concentrations from the previous day, sampling in the afternoon during active sediment placement, and occasional highfrequency sampling during the day or night to track the temporal evolution and variability of suspended-sediment concentrations. The early morning and overnight sampling was done by Meg Rippy of Scripps Institute of Oceanography, who also collected samples for nutrient and bacteria analyses. Results of these additional samples are not included in this report and will be presented and summarized in her dissertation research. The other samples were collected by USGS staff and volunteers and did not include nutrient or bacteria samples.

All beach-water samples were processed for suspended-sediment concentration and grain-size distributions at the USGS PCMSC Sediment Laboratory in Menlo Park, California. One of the duplicate water samples obtained from the beaches was processed to determine suspended-sediment concentration. These samples were wet sieved through a $63-\mu \mathrm{m}$ sieve, which separated the sample into sand (greater than $63 \mu \mathrm{m}$ ) and mud (less than $63 \mu \mathrm{m}$ ) fractions. The volume of water was measured with a graduated cylinder. The sand fraction was dried, weighed, and processed through the Beckman Coulter LS230 for particle-size distribution. The mud fraction was filtered through pre-tared glass fiber filters, dried, and weighed. The weights of the sand and mud fractions allowed for the determination of the mud concentration, sand concentration, and - through summation - the total sediment concentration. The suspended sand concentrations were exceptionally high in almost all of these samples owing to the resuspended native beach sand in the swash zone; however, suspended mud concentrations were low (approximately $10 \mathrm{mg} / \mathrm{L}$ or less) in waters without influence from the sediment placement and high $(10 \mathrm{~s}$ to $100 \mathrm{~s}$ of $\mathrm{mg} / \mathrm{L})$ in waters influenced by the placement.

The majority of samples had adequate mass of mud-sized sediment in the duplicate sample to characterize the grain-size distribution of the mud fraction (that is, less than $63 \mu \mathrm{m}$ ). Samples were first wet sieved through a $63-\mu \mathrm{m}$ sieve, and the liquid and sediment passing through the sieve were collected in a graduated cylinder. The retained sediment was oven dried, and the the particle-size distribution of this sediment was determined with the Beckman Coulter LS230 analyzer. Results of the swash-water sampling are provided in appendix 4.

\section{Coastal-Water Sampling-Small Vessel}

Coastal waters were sampled at regular stations from a small research vessel for water properties, turbidity, and suspended-sediment concentrations. A station list and map are included in table 4 and figure 1, respectively. Coastal-water properties were measured using a Sea-Bird Electronics SEACAT 19Plus Profiler CTD (conductivity, temperature, and depth) sensor (fig. 6). Also attached to the CTD were a Wetlabs 650-nm (red) C-Star transmissometer with a 25-cm pathlength and a D\&A Instruments 850-nm (infrared) OBS-3 turbidity sensor, which were both powered and logged by the CTD. The CTD and additional instruments were sampled at $4 \mathrm{~Hz}$. At each station the CTD was turned on and lowered into the water. Once the pump was primed, the CTD was raised to just below the water surface and then lowered to the seafloor at a rate of approximately $0.5 \mathrm{~m} / \mathrm{sec}$. CTD and turbidity data were output in engineering units (salinity, temperature, density, depth, beam attenuation, and optical backscatterance) using the Sea-Bird Seasoft software, and only the downcast portion of the output was utilized and reported here. The CTD data are provided in appendix 5. 


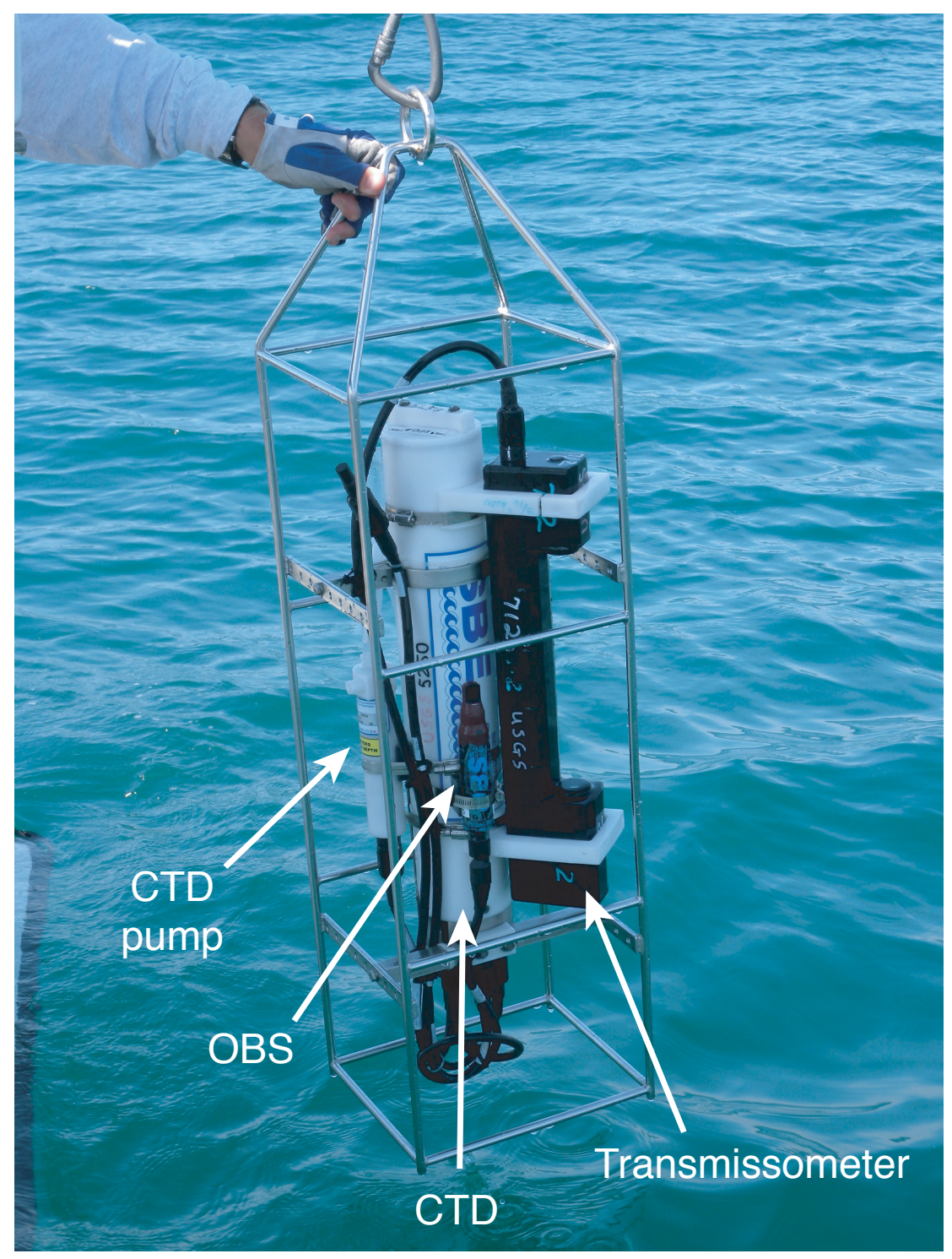

Figure 6. Photograph of the conductivity-temperature-depth (CTD) instrument with the additional optical backscatterance sensor (OBS) and 25-cm pathlength transmissometer.

After profiling the water column with the CTD, a surface-water grab sample was obtained at approximately $25 \mathrm{~cm}$ below the water surface directly into a 1-L Nalgene bottle for suspended-sediment concentration analysis. Samples were analyzed at the USGS PCMSC Sediment Laboratory in Menlo Park, California, with the mud-fraction techniques for determining suspended-sediment concentration for the swash samples as detailed above. Particle grain-size distributions were not evaluated for any of these water samples. Concentration data are provided in appendix 6.

\section{Aerial Remote Sensing}

High-resolution multispectral imagery was obtained to help determine the dispersal pathways of fine sediment on the beach under various environmental conditions of the Demonstation Project. The imagery also was collected to augment field measurements from moored and vessel-based instruments and aid in their data interpretation. Ocean Imaging 
Corporation (OI), based in Solana Beach, California, was contracted to collect and process multispectral imagery. For the Demonstatration Project, OI operated the DMSC-Mk2 aerialimaging system manufactured by SpecTerra, Limited, in Australia. This sensor provides 12-bit radiometric resolution digital data from 4 independent channels. The channel wavelengths are customizable to any wavelength combination between 400 and $950 \mathrm{~nm}$. Additionally, OI's aerial-imaging system included a fully integrated thermal infrared (IR) camera manufactured in Germany by Jenoptik as a fifth channel. This camera allowed for simultaneous acquisition of multispectral visible, near IR, and thermal IR imagery. Positional information for each image frame and aircraft roll, pitch, and yaw information needed to correct the image frames for viewing geometry is supplied by an integrated differential GPS and an inertial motion sensing unit (IMU) manufactured by Oxford Technologies of England.

For this project, the sensor channels of the imaging system were configured with the following interference filters with 10-nm bandwith: 450, 551, 577, and $640 \mathrm{~nm}$. The wavelengths were chosen based on deductive spectrometer analyses (see below) in order to maximize the potential for detecting suspended sediment and to separate the newly deposited sediment spectrally from resuspended native beach and shelf sediment. The imagery was collected at an altitude of $1,372 \mathrm{~m}$, resulting in spatial resolution of $70 \mathrm{~cm}$.

Following each image data acquisition, the image frames were subject to pre-processing algorithms for band-to-band alignment and vigneting correction. Each image set was then run through a calibration procedure, which was necessary to enable quantitative comparisons between multiple image sets collected under differing sun angle and atmospheric conditions. The calibration method utilizes a standard white teflon target that is imaged before each flight by both the DMSC sensor and an Ocean Optics Spectrometer. Additional Teflon spectra also are taken during the flight with the spectrometer. The measured output values from the sensor are compared to the irradiance values measured from the spectrometer to determine a calibration factor for each band. This factor is applied to each frame in the dataset before the frames are mosaicked into a final image. The result is a band-to-band standardization of the reflectance signal over an evenly reflecting target (the Teflon) during the entire image acquisition time interval to account for changes in atmospheric attenuation and sun angle. The system-integrated IMU and autogeoreferencing software that uses the IMU information results in circular error geopositioning accuracies of 3-7 pixels. In order to increase the final image accuracy, the individual image frames were further manually adjusted for any systematic bias to match a USGS orthoquad 1-m-resolution image of the beach and inshore areas. Remote-sensing imagery was output in truecolor using the red, green, and blue wavelengths. These images are available in GeoTIFF format with additional metadata in appendix 7.

\section{Oceanographic Observations-Tripods and Moored Buoys}

The USGS deployed several bottom platforms and moored buoys offshore of the Demonstration Project to record oceanographic conditions before, during, and after sediment placement. Three types of platforms were used for this study: tripods, trawl-resistent bottom mounts (TRBMs), and moored buoys (fig. 7). A summary of the locations and depths of these platforms for each phase of this study area is provided in tables 6 and 7. Each platform contained oceanographic sensors to characterize water properties, flow conditions, and suspended-sediment properties in the water. 

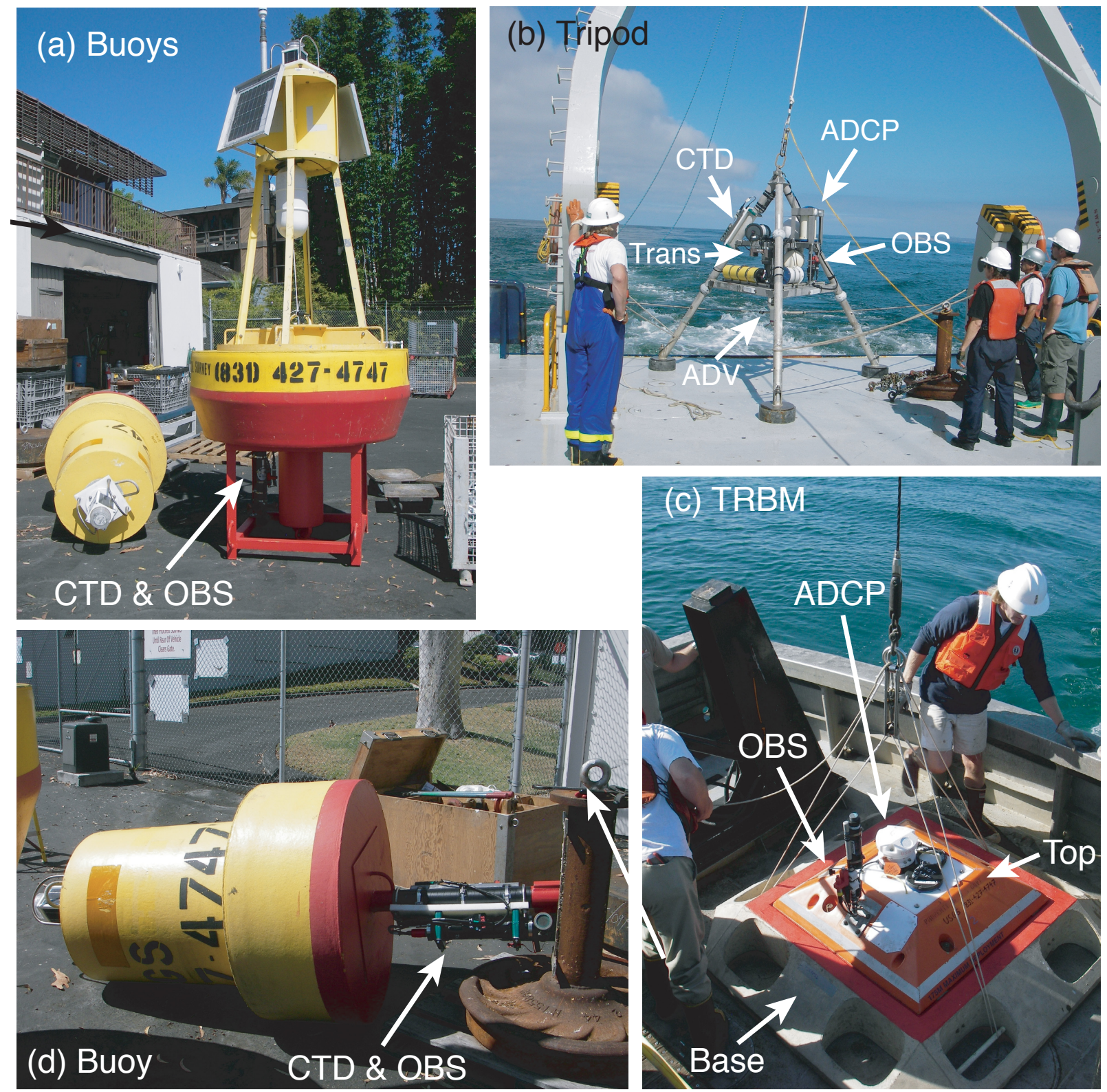

Figure 7. Photographs of moorings utilized in the Demonstration Project, including (a, d) buoys, (b) tripods, and (c) trawl-resistent bottom mounts (TRBMs).

Table 6. Oceanographic platform stations for Phase I (2008) of the Demonstration Project.

\begin{tabular}{|l|l|l|l|l|}
\hline \multicolumn{1}{|c|}{ Station Name } & \multicolumn{1}{|c|}{ Description } & $\begin{array}{c}\text { Water Depth } \\
(\mathbf{m})\end{array}$ & $\begin{array}{c}\text { Latitude } \\
\text { (decimal degrees) }\end{array}$ & $\begin{array}{c}\text { Longitude } \\
\text { (decimal degrees) }\end{array}$ \\
\hline TJR08C1S & Central Inshore Buoy & 13.5 & 32.542567 & -117.139450 \\
\hline TJR08C2S & Central Offshore Buoy & 18.5 & 32.540667 & -117.156950 \\
\hline TJR08C1T & Central Inshore Tripod & 13.4 & 32.542583 & -117.138517 \\
\hline TJR08C2T & Central Offshore Tripod & 19.2 & 32.540183 & -117.157583 \\
\hline TJR08N1T & Northern TRBM & 14 & 32.548552 & -117.141950 \\
\hline TJR08S1T & Southern TRBM & 14 & 32.534883 & -117.136833 \\
\hline
\end{tabular}


Table 7. Oceanographic platform stations for Phase II (2009) of the Demonstration Project.

\begin{tabular}{|l|l|c|l|l|}
\hline \multicolumn{1}{|c|}{ Station Name } & \multicolumn{1}{|c|}{ Description } & $\begin{array}{c}\text { Water Depth } \\
(\mathbf{m})\end{array}$ & $\begin{array}{c}\text { Latitude } \\
\text { (decimal degrees) }\end{array}$ & $\begin{array}{c}\text { Longitude } \\
\text { (decimal degrees) }\end{array}$ \\
\hline TJR09N1S & Northern Buoy & 15 & 32.548050 & -117.141917 \\
\hline TJR09S1S & Southern Buoy & 15 & 32.538400 & -117.137833 \\
\hline TJR09N1T & Northern Tripod & 15 & 32.547900 & -117.141100 \\
\hline TJR09S1T & Southern Tripod & 15 & 32.538167 & -117.137083 \\
\hline
\end{tabular}

The tripods housed numerous instruments for the purpose of measuring water flow and properties, including temperature, salinity, and turbidity. Tripods housed: (1) upward-facing acoustic Doppler current profilers (ADCPs) to obtain profiles of overlying currents and, when available, directional wave spectra; (2) downward-facing acoustic current profilers (AquaDopps) to obtain detailed profiles of currents down to the seabed - although these instruments failed to record adequate data; (3) near-bottom single-point current meters (ADVs) capable of current and directional wave measurements; (4) conductivity, temperature, and depth (CTD) sensors; (5) optical backscatterance sensors (OBSs) and light transmissometers to measure turbidity; and (6) a LISST laser particle size distribution analyzer. The OBSs were housed with brushes to clean the sensor faces regularly. Detailed descriptions of these instruments are presented below.

Two TRBMs were utilized during Phase I of the Demonstration Project. These TRBMs were housed with ADCPs to obtain profiles of overlying currents and OBSs with automated wipers to measure turbidity. Moored buoys were deployed with CTD and OBS sensors to measure water properties just below the ocean surface. Two buoys were utilized for both Phase I and II of the project, although they were located at different sites each year (tables 6 and 7; fig. 1). Below is a description of the instrument types utilized for this study. Detailed descriptions of the instrumentation and setup for each platform is provided in tables 8 and 9 .

\section{Acoustic Doppler Current Profilers (ADCP and ADP)}

ADCPs and ADPs estimate current velocities in the water by sending an acoustic pulse and measuring the Doppler shift of the returned echos, which are reflected back by particulate matter. The instruments can obtain a profile of current velocity by measuring the Doppler shift at different time lags, which correspond to different distances away from the instrument. ADCPs and ADPs also provide measurements of the acoustic backscatter intensity throughout the profiled water column, which is a function of the amount and type of particles in the water.

For this project RDI Workhorse $1200 \mathrm{KHz}$ ADCPs and Nortec $1 \mathrm{MHz}$ AWAC ADPs were used to measure mean flow rates and directional wave properties, which included wave height, period, and direction. For profiles of currents, each instrument was sampled at $2 \mathrm{~Hz}$ for $30 \mathrm{sec}$, resulting in 60 pings. All ADCPs were set to record currents in 1-m vertical bins. These instruments also measured directional wave parameters every $2 \mathrm{hrs}$ in 20-min burst intervals.

\section{AquaDopp Current Profiler}

A Nortek AquaDopp current profiler was used to measure current profiles immediately above the seafloor at the tripod locations, although the system did not properly record data. 
Table 8. Oceanographic instrumentation for the stations during Phase I (2008) of the Demonstration Project.

\begin{tabular}{|c|c|c|c|c|}
\hline Station Name & Description & Sensor Type & $\begin{array}{l}\text { Sampling } \\
\text { depth or } \\
\text { height } 1\end{array}$ & Sampling schedule and notes \\
\hline \multirow[t]{2}{*}{ TJR09N1S } & Inshore Buoy & FSI Inductive CTD & $0.94 \mathrm{mbw}^{2}$ & $5 \mathrm{~min}$ \\
\hline & & D\&A OBS3 & $0.84 \mathrm{mbw}^{2}$ & 5 min, OBS at high gain setting \\
\hline \multirow[t]{2}{*}{ TJR08C2S } & Offshore Buoy & FSI Inductive CTD & $0.95 \mathrm{mbw}^{2}$ & $5 \mathrm{~min}$ \\
\hline & & D\&A OBS3 & $0.85 \mathrm{mbw}^{2}$ & 5 min, OBS at high gain setting \\
\hline \multirow[t]{9}{*}{ TJR08C1T } & Inshore Tripod & RDI $1200 \mathrm{kHz}$ ADCP & $2.04 \mathrm{mab}$ & Currents at $5 \mathrm{~min}$ \\
\hline & & Sontek ADV-O & $0.65 \mathrm{mab}$ & 15 min, downward looking \\
\hline & & Nortek Aquadopp Profiler & $1.05 \mathrm{mab}$ & $\begin{array}{l}\text { Downward looking, Instrument } \\
\text { failed }\end{array}$ \\
\hline & & D\&A OBS3 & $1.50 \mathrm{mab}$ & $\begin{array}{l}15 \mathrm{~min}, \text { OBS at medium gain } \\
\text { setting }\end{array}$ \\
\hline & & D\&A OBS3+ & $0.34 \mathrm{mab}$ & $\begin{array}{l}5 \mathrm{~min}, \text { OBS dual range at } 0-250 \text { and } \\
0-1000\end{array}$ \\
\hline & & $\begin{array}{l}\text { Wetlabs } 10 \mathrm{~cm} \\
\text { transmissometer }\end{array}$ & $1.49 \mathrm{mab}$ & $15 \mathrm{~min}$ \\
\hline & & Sequoia LISST & $0.35 \mathrm{mab}$ & $\begin{array}{l}5 \text { min, sensor failed within days of } \\
\text { deployment }\end{array}$ \\
\hline & & SBE Microcat CT & $1.95 \mathrm{mab}$ & $5 \mathrm{~min}$ \\
\hline & & Paroscientific Pressure Sensor & $1.05 \mathrm{mab}$ & $15 \mathrm{~min}$ \\
\hline \multirow[t]{7}{*}{ TJR08C2T } & Offshore Tripod & Nortek $1 \mathrm{MHz}$ AWAC ADP & $2.02 \mathrm{mab}$ & $\begin{array}{l}\text { Currents at } 5 \mathrm{~min}, \text { waves at } 2 \mathrm{hr}, \\
\text { sensor failed between Oct- } 31 \text { and } \\
\text { Nov-23, } 2008\end{array}$ \\
\hline & & Sontek ADV-O & $0.67 \mathrm{mab}$ & 15 min, downward looking \\
\hline & & D\&A OBS3 & $1.48 \mathrm{mab}$ & $15 \mathrm{~min}, \mathrm{OBS}$ at medium gain \\
\hline & & D\&A OBS3+ & $0.28 \mathrm{mab}$ & $\begin{array}{l}5 \mathrm{~min} \text {, OBS dual range at } 0-250 \text { and } \\
0-1000 \text {, sensor failed between Oct- } \\
31 \text { and Nov- } 23,2008\end{array}$ \\
\hline & & $\begin{array}{l}\text { Wetlabs } 25 \mathrm{~cm} \\
\text { transmissometer }\end{array}$ & $1.48 \mathrm{mab}$ & $15 \mathrm{~min}$ \\
\hline & & SBE Microcat CTD & $1.67 \mathrm{mab}$ & $5 \mathrm{~min}$ \\
\hline & & Paroscientific Pressure Sensor & $1.26 \mathrm{mab}$ & $15 \mathrm{~min}$ \\
\hline \multirow[t]{2}{*}{ TJR08N1T } & Northern TRBM & Nortek $1 \mathrm{MHz}$ AWAC ADP & $0.68 \mathrm{mab}$ & Currents at $5 \mathrm{~min}$ \\
\hline & & D\&A OBS3+ & $0.75 \mathrm{mab}$ & $\begin{array}{l}5 \text { min, OBS dual range at } 0-500 \text { and } \\
0-2000\end{array}$ \\
\hline \multirow[t]{2}{*}{ TJR08S1T } & Southern TRBM & Nortek $1 \mathrm{MHz}$ AWAC ADP & $0.68 \mathrm{mab}$ & Currents at $5 \mathrm{~min}$ \\
\hline & & D\&A OBS3+ & $0.75 \mathrm{mab}$ & $\begin{array}{l}5 \mathrm{~min}, \text { OBS dual range at } 0-500 \text { and } \\
0-2000\end{array}$ \\
\hline
\end{tabular}

${ }^{1}$ - Sensor depths are shown in meters below the water surface (mbw) and sensor heights are shown in meters above the bed (mab).

${ }^{2}$ - The depth of the CTD calculated by the median pressure value of record. The depth of the OBS calculated by the measured vertical difference between the CTD and OBS sensors. 
Table 9. Oceanographic instrumentation for the stations during Phase II (2009) of the Demonstration Project.

\begin{tabular}{|c|c|c|c|c|}
\hline Station Name & Description & Sensor Type & $\begin{array}{l}\text { Sampling } \\
\text { depth or } \\
\text { height }{ }^{1}\end{array}$ & Sampling intervals and notes \\
\hline \multirow[t]{2}{*}{ TJR09N1S } & $\begin{array}{l}\text { Northern } \\
\text { Buoy }\end{array}$ & FSI Inductive CTD & $0.67 \mathrm{mbw}$ & $5 \mathrm{~min}$ \\
\hline & & D\&A OBS3 & $0.56 \mathrm{mbw}$ & $5 \mathrm{~min}$; OBS at high gain setting \\
\hline \multirow[t]{2}{*}{ TJR09S1S } & $\begin{array}{l}\text { Southern } \\
\text { Buoy }\end{array}$ & FSI Inductive CTD & $1.03 \mathrm{mbw}$ & $5 \min$ \\
\hline & & D\&A OBS3 & $0.91 \mathrm{mbw}$ & $5 \mathrm{~min}$; OBS at high gain setting \\
\hline \multirow[t]{8}{*}{ TJR09N1T } & $\begin{array}{l}\text { Northern } \\
\text { Tripod }\end{array}$ & RDI $1200 \mathrm{kHz}$ ADCP & $2.03 \mathrm{mab}$ & Currents at $5 \mathrm{~min}$, waves at $2 \mathrm{hr}$ \\
\hline & & Sontek ADV-O & $0.65 \mathrm{mab}$ & $\begin{array}{l}\text { Currents at } 15 \text { min, waves at } 30 \\
\text { min, downward looking }\end{array}$ \\
\hline & & Nortek Aquadopp Profiler & 1.05 & $\begin{array}{l}\text { Currents at } 5 \mathrm{~min} \text {, downward } \\
\text { looking, instrument failed }\end{array}$ \\
\hline & & D\&A OBS3 & $1.50 \mathrm{mab}$ & $\begin{array}{l}15 \text { min, OBS at medium gain } \\
\text { setting }\end{array}$ \\
\hline & & D\&A OBS3+ & $0.34 \mathrm{mab}$ & $\begin{array}{l}5 \mathrm{~min}, \text { OBS dual range at } 0-250 \\
\text { and } 0-1000\end{array}$ \\
\hline & & Wetlabs $25 \mathrm{~cm}$ transmissometer & $1.50 \mathrm{mab}$ & $15 \min$ \\
\hline & & SBE Microcat CT & $1.82 \mathrm{mab}$ & $5 \mathrm{~min}$ \\
\hline & & Paroscientific Pressure Sensor & $1.55 \mathrm{mab}$ & $15 \mathrm{~min}$ \\
\hline \multirow[t]{6}{*}{ TJR09S1T } & $\begin{array}{l}\text { Southern } \\
\text { Tripod }\end{array}$ & RDI $1200 \mathrm{kHz}$ ADCP & $2.02 \mathrm{mab}$ & Currents at $5 \mathrm{~min}$, waves at $2 \mathrm{hr}$ \\
\hline & & Sontek ADV-O & $0.67 \mathrm{mab}$ & $\begin{array}{l}\text { Currents at } 15 \text { min, waves at } 60 \\
\text { min, downward looking }\end{array}$ \\
\hline & & D\&A OBS3 & $1.48 \mathrm{mab}$ & $\begin{array}{l}15 \mathrm{~min}, \mathrm{OBS} \text { at medium gain } \\
\text { setting }\end{array}$ \\
\hline & & Wetlabs $25 \mathrm{~cm}$ transmissometer & $1.50 \mathrm{mab}$ & $15 \mathrm{~min}$ \\
\hline & & SBE Microcat CT & $1.64 \mathrm{mab}$ & $5 \mathrm{~min}$ \\
\hline & & Paroscientific Pressure Sensor & $1.56 \mathrm{mab}$ & $15 \mathrm{~min}$ \\
\hline
\end{tabular}

${ }^{1}$ - sensor depths are shown in meters below the water surface (mbw) and sensor heights are shown in meters above the bed (mab).

\section{Acoustic Doppler Velocimeters (ADV)}

An ADV measures current speed and direction in three directions ( $\mathrm{u}, \mathrm{v}$, and $\mathrm{w})$ at a single point within a small sampling volume by using the Doppler principle to calculate velocity along three axes. This study utilized Sontek/YSI, Inc., ocean versions, or "ADV-O," which operate at 5 $\mathrm{MHz}$ and measure velocities in a sample volume of $\sim 2 \mathrm{~cm}^{3}$ located $\sim 18 \mathrm{~cm}$ from the acoustic transmitter. The data were logged using Sontek Hydra data loggers, which also logged data from two other sensors (typically a transmissometer and an OBS). The ADV-Os were sampled for both mean currents and directional wave spectra.

\section{Optical Backscatter Sensors (OBS)}

An OBS measures turbidity by sending a beam of infrared light into the water and then measuring the quantity of light that is reflected back to its sensor from suspended particles. Suspended-sediment concentration can then be determined if the sensor is calibrated for the sediment in suspension. Two models of D\&A Instruments' OBSs were used, single channel 
OBS3s and dual channel OBS3+s. Tables 8 and 9 include the gain settings for each OBS3 sensor (high, medium, or low).

\section{Light Transmissometers}

A transmissometer measures the transmission of red collimated light $(650 \mathrm{~nm}$ wavelength) from an LED along a fixed path through the water. WET Labs C-Star transmissometers with either $10-\mathrm{cm}$ or $25-\mathrm{cm}$ pathlengths were used.

\section{Conductivity-Temperature (CT) and Conductivity-Temperature-Depth (CTD) Recorders}

Conductivity-temperature (CT) sensors measure and record water temperature and conductivity, from which salinity can be calculated using the 1978 Practical Salinity Scale (Unesco, 1981). Conductivity-temperature-depth (CTD) sensors also include a pressure sensor to measure water depth by using the hydrostatic assumption. Seabird Electronics (SBE) sensors (both SBE-37 MicroCAT and a SBE-16 SeaCAT) were used in this study.

\section{Oceanographic Data Processing}

Data from the oceanographic sensors were processed using standards recommended by the instrument manufacturers. Processed time-series of these data are available in appendix 8. A description of the data processing and file formats follows.

\section{Data-File Identifiers}

Data files were produced for either individual instruments or groups of related instruments from each oceanographic platform. Data files were uniquely identified by both the mooring identification number (mooring ID) and information about the instrument(s) and file type. First, a five-part mooring ID was assigned to each mooring and tripod. The mooring ID also can be used to identify and/or locate data records in the USGS Woods Hole Science Center time-series data management system (Montgomery and others, 2008). Each part of the mooring ID represents unique characteristics of the station: the first three characters describe the project ("TJR" for Tijuana River Demonstration Project ), the next two characters describe the project year ("08" or "09"), the next character describes the general location (for example, "N" for northern, "C" for central, " $\mathrm{S}$ " for southern), the next character is the platform number at that site ("1" or " 2 "), and the next character represents the station type ("T" for tripod or TRBM and "S" for surface buoy). For example, the mooring ID for the central tripod during Phase I of the Demonstration was "TJR08C1T." Data files are labeled first by mooring ID, second by instrument number and code, and lastly by the file-type extension. For example, the data file from the microcat CT sensor ("mc"), which was the second instrument ("02") on tripod described above was denoted "TJR08C1T02mc.nc". A complete list of instrument codes is provided in appendix 8.

Raw data files downloaded from each instrument were translated from the manufacturerspecific data format into the netCDF data-file format using toolboxes developed in Matlab software specific to each instrument. The netCDF data-file format, developed by the Unidata Corporation (http://www.unidata.ucar.edu/software/netcdf/), is a compact binary format compatible with most computer systems, which stores both the data and the metadata in the file. The USGS uses the EPIC conventions for organizing and naming oceanographic data variables (http://www.epic.noaa.gov/epic/document/convention.htm). These data were processed using quality-control procedures developed for all USGS Woods Hole Science Center oceanographic data. Files generated during the first processing step (which involved conversion to engineering units and quality assurance calculations) were stored in netCDF format with .cdf suffixes. Final 
versions (after application of calibration coefficients, coordinate transformations, rotation to geographic coordinates, and averaging of good data) were stored in netCDF format with .nc extensions. All of the final statistics data are in EPIC-compliant netCDF format. Burst-data files also are in netCDF format, but are not EPIC-compliant because they use an added dimension (sample number) not used by the EPIC convention.

Time

Times are reported in Universal Time (UT, equivalent to Greenwich Mean Time, GMT). Drift of instrument clocks was checked by comparing instrument times with accurate times from either the GPS or clocks synchronized with the National Institute of Standards and Technology in Boulder, Colorado (http://tf.nist.gov/) before and after deployments. The observed offsets were small compared to the sample intervals, so instrument times in this data set were not adjusted.

Time is recorded in the netCDF files as two variables named time 1 and time2, in compliance with EPIC standards, to allow precise storage of time in integer format. Timel is the Julian day, where midnight on May 23, $1968=2440000$ and time 2 is the elapsed time on that day, in milliseconds since midnight. Thus, time in Julian days is computed as time1+time $2 /(1,000 \times 3,600 \times 24)$.

\section{Current Meter Data}

\section{Instrument Orientations}

Each of the ADVs and ADCPs had internally mounted flux-gate compasses. These were calibrated prior to deployment according to manufacturer's recommendations. Raw ADCP data were recorded in beam coordinates. Data from the ADVs were recorded in instrument coordinates (referred to here as $\mathrm{x}, \mathrm{y}, \mathrm{z}$ coordinates) and later rotated into geographic coordinates using burst-median values for heading, pitch, and roll. All data were then rotated to true geographic coordinates ( $\mathrm{u}, \mathrm{v}$, and w, where positive is toward east, north, and up) by using instrument compasses and tilt sensors and correcting for local magnetic variation $\left(13.8^{\circ} \mathrm{E}\right)$.

\section{Acoustic Doppler Current Meter (ADCP) Data}

ADCP data were processed according to standard USGS procedures by using ADCP Tools, a collection of Matlab routines written to read in and process raw ADCP data and create netCDF files of the raw and processed data. The toolbox is described in USGS Open-File Report 00-458 (Côté and others, 2011). Raw data files from the ADCPs were converted to netCDF format and checked for clock accuracy by comparing in-and-out-of-water times to the mooring log and by checking for linear time progression. Data were despiked, with gaps replacing bad data points. The clock, ADCP calibrations, and internal compass were compared to nearby instruments for consistency. Data from the four beams were compared in pairs for symmetry and checked for high-intensity reflections indicative of fish or other beam obstructions. Bad values were masked both manually and automatically and, where possible, a three-beam solution was used to fill in gaps caused by a compromised beam. Data above the water surface were masked; because the water depth at the site varies with the stage of the tide, there are periods where some bins above the water surface are retained within the file. Data collected before the instrument was on the seafloor or after recovery were trimmed off. Finally, the data from beam coordinates were rotated into geographic coordinates. The final processed versions of these data were stored in EPIC-compliant format. 


\section{Acoustic Doppler Velocimeter (ADV) Data}

The ADVs were set to record velocities in instrument coordinates, which were rotated into earth coordinates using data from the internal compass and tilt sensor. In addition to velocities, the ADV logged data on the amplitude and correlation of the return signal, sound speed, range to boundary, compass and tilt, pressure (from an external Paroscientific Digiquartz pressure gauge connected to the ADV), and the external optical sensors. Data from each ADV (and the attached external sensors) was logged by an individual Sontek Hydra datalogger and stored in binary format. The data in these files were processed using a series of Matlab routines in the Hydratools toolbox developed by the USGS (Martini and others, 2005).

\section{Optical Backscatter Sensor (OBS) Data}

The Sontek Hydra data logger converted raw OBS voltage measurements to counts with a 14-bit analog-digital converter. Counts were converted to volts (a linear conversion) during processing so that the data could be calibrated to sediment concentration from laboratory-derived calibration coefficients. The data are available in the .nc file for the instrument to which the OBS was connected.

\section{Transmissometer Data}

The Sontek Hydra data loggers also logged transmissometer data in counts; a linear conversion was necessary to convert counts to volts. The Seabird SeaCAT and the RBR Brancker loggers, however, logged the raw voltage. The transmissometer data can be presented either as percentage of light transmission (from 0 to 100, the former being completely occluded) or in terms of beam attenuation in units of $1 / \mathrm{m}$ (utilizing another linear conversion with the instrument pathlength). The advantage of presenting the data as $1 / \mathrm{m}$ is that values increase as the suspended load increases, and these values are independent of the light pathlength. The final data are available in the .nc file for the instrument with which the transmissometer was deployed (ADV, PCADP, or Seacat).

\section{MicroCAT (MC)}

Software provided by SeaBird Electronics was used to convert the time series of raw conductivity measurements recorded by the MicroCATs into salinity. The SeaBird software also was used to calculate water density from the temperature and salinity measurements. The data were converted to ASCII format and then translated to netCDF. Data were despiked and gaps were filled by interpolation where possible. The clock and calibrations were compared to nearby instruments for consistency. Processed versions of these data files are available in EPICcompliant netCDF format.

\section{Additional Data-Collection Resources}

Additional data from the study area were collected by agencies unassociated with this project, and these data are available from the collecting agencies. These data sources and their links are identified below. Because the USGS and its partners did not collect these data, information about the accuracy or availability of these data cannot be provided here. Furthermore, although the Web-based links listed below were current at the time of publication of this report, they may be modified or removed in the future.

\section{Weather and Hydrology}

Ocean and meteorological-condition data collected during the Demonstration Project are available through NOAA's National Data Buoy Center (NDBC), the Scripps Institution of Oceanography's Coastal Data Information Program (CDIP), and the International Boundary 
Water Commission (IBWC). The NDBC (http://www.ndbc.noaa.gov/) provides weather and ocean observations from numerous stations within the region, including the following buoys:

Station 46086-San Clemente Basin, California $\left(32.491^{\circ} \mathrm{N}, 118.034^{\circ} \mathrm{W}\right)$,

Station 46232-Point Loma South, California $\left(32.530^{\circ} \mathrm{N}, 117.431^{\circ} \mathrm{W}\right)$, and

Station 46231-Mission Bay, California $\left(32.748^{\circ} \mathrm{N}, 117.370^{\circ} \mathrm{W}\right)$.

The NDBC also provides land-based weather-station data, including Station TIQC1-Oneonta Slough, Tijuana River Reserve, California $\left(32.568^{\circ} \mathrm{N}, 117.131^{\circ} \mathrm{W}\right)$, which is owned and maintained by the National Estuarine Research Reserve System.

During the Demonstration Project, the CDIP program (http://cdip.ucsd.edu/) operated a directional wave buoy near the study area. Directional wave data from this buoy are available from the CDIP Web site under Station 155-Imperial Beach Nearshore, California $\left(32.5695^{\circ} \mathrm{N}\right.$, $\left.117.1691^{\circ} \mathrm{W}\right)$. The Imperial Beach Nearshore buoy was decommissioned in January 2010.

Water-discharge data for the Tijuana River were collected at the United States-Mexico International Border at Station 11-0133.00 by the IBWC. These data are are tabulated and available from the Water Data Web site of the IBWC (http://www.ibwc.state.gov/Water_Data/rtdata.htm).

\section{Beach Topographic Mapping}

The USGS funded the SIO Southern California Beach Processes Study (SCBPS) (http://cdip.ucsd.edu/SCBPS/) to do topographic mapping of the study area beach for the duration of the 2008-2009 Demonstration Project. Unfortunately, the SIO group was not able to collect topographic data for the duration of the Demonstration Project. The data collected are available at the SCBPS Web site (http://cdip.ucsd.edu/SCBPS/?nav=data).

\section{References Cited}

Côté, J.M., Hotchkiss, F.A., Martini, M., and Denham, C.R., 2011, Acoustic Doppler Current Profiler (ADCP) data processing system manual: U.S. Geological Survey Open-File Report 00-458, v. 4, 51 p. (also available at: http://pubs.usgs.gov/of/2000/of00-458/).

Farnsworth, K.L., and Warrick, J.A., 2007, Sources, dispersal, and fate of fine sediment supplied to coastal California: U.S. Geological Survey Scientific Investigations Report 20075254, $77 \mathrm{p}$.

Flick, R.E., 1993, The myth and reality of southern California beaches: Shore \& Beach, v. 61, no. 3, p. 3-13.

Folk, R.L., and Ward, W.C., 1957, Brazos River bar - a study in the significance of grain size parameters: Journal of Sedimentary Petrology, v. 27, p. 3-26.

Fowlera, S.W., 1990, Critical review of selected heavy metal and chlorinated hydrocarbon concentrations in the marine environment: Marine Environmental Research, v. 29, no. 1, p. 1-64.

Inman, D.L., 1952, Measures for describing the size distribution of sediments: Journal of Sedimentary Petrology, v. 22, no. 3, p. 125-145.

Inman, D.L., 1976, Summary report of man's impact on the California coastal zone: Prepared for the State of California Department of Navigation and Ocean Development, $150 \mathrm{p}$.

Inman, D.L., and Jenkins, S.A., 1999, Climate change and the episodicity of sediment flux of small California rivers: Journal of Geology, v. 107, no. 3, p. 251-270. 
Kuhn, G.G., and Shepard, F.P., 1984, Sea cliffs, beaches, and coastal valleys of San Diego County - Some amazing histories and some horrifying implications: Berkeley, University of California Press, 194 p. (also available at http://ark.cdlib.org/ark:/13030/ft0h4nb01z/).

Martini, M., Sherwood, C., Horwitz, R., Ramsey, A., Lightsom, F., Lacy, J., and Xu, J., 2005, Hydratools manual version 1.0, documentation for a MATLAB ${ }^{\circledR}-$ based post-processing package for the Sontek Hydra: U.S. Geological Survey Open-File Report 2005-1026 (also available at: http://pubs.usgs.gov/of/2005/1026/).

Montgomery, E.T., Martini, M.A., Lightsom, F.L., and Butman, B., 2008, Documentation of the U.S. Geological Survey oceanographic time series measurement database: U.S. Geological Survey Open-File Report 2007-1194 (also available at: http://pubs.usgs.gov/of/2007/1194/).

Noble, M., and Xu, J., 2004, Coastal circulation and transport patterns; The likelihood of OCSD's plume impacting Huntington Beach shoreline: U.S. Geological Survey Open File Report 2004-1019, 342 p. (also available at: http://pubs.usgs.gov/of/2004/1019/).

Olsen, C.R., Cutshall, N.H., and Larsen, I.L., 1982, Pollutant-particle associations and dynamics in coastal marine environments - a review: Marine Chemistry, v. 11, no. 6, p. 501-533.

Rubin, D.M., Chezar, H., Harney, J.N., Topping, D.J., Melis, T.S., and Sherwood, C.R., 2007, Underwater microscope for measuring spatial and temporal changes in bed-sediment grain size: Sedimentary Geology, v. 202, no. 3, p. 402-408.

San Diego Association of Governments (SANDAG), 2012, San Diego Regional Sand ProjectFact Sheet: San Diego, Calif., SANDAG, 2 p. (also available at: http://www.sandag.org/uploads/publicationid_340_1057.pdf).

Svejkovsky J., Nezlin, N.P., Mustain, N.M., and Kum, J.B., 2010, Tracking stormwater discharge plumes and water quality of the Tijuana River with multispectral aerial imagery: Estuarine, Coastal and Shelf Science, v. 87, no. 3, p. 387-398.

Trask, P.D., 1932, Origin and environment of source sediments of petroleum: Houston, Tex., Gulf Publishing Co., 323 p.

Unesco, 1981, The practical salinity scale 1978 and the international equation of state of seawater 1980: Technical Paper of Marine Science, v. 36, 25 p.

Zedler, J.B., Nordby, C.S., and Kus, B.K., 1992, The ecology of Tijuana Estuary-A national estuarine research reserve: Washington, D.C., National Oceanic and Atmospheric Administration, Office of Coastal Resource Management, Sanctuaries and Reserves Division, $104 \mathrm{p}$.

\section{Appendixes}

\section{Appendix 1 - Sediment grain-size distribution data from the pre-placement stockpile.}

(Files available at

http://pubs.usgs.gov/of/2012/1083/of2012-1083_appendixes/of2012-1083_appendix_1/)

Grain size distribtion data from the stockpile sediment samples are provided in the workbook: Appendix_1_Results. There are three sheets within this file: 
Progress - A summary of the completion dates for the laboratory methods utilized for these analyses.

Weights - Raw weights and computed weight-based percentages of the sediment samples from grain-size sieving.

$\boldsymbol{S D S Z}$ - The integrated grain-size distribution results for the sediment samples. Results are presented in the weight-based percentage of sample in 0.25 -phi classes. In addition to these results, a number of sediment statistics were calculated using the USGS SEDSIZE software. Further details about SEDSIZE can be found at $h t t p: / / w a t e r . u s g s . g o v / c g i-$ bin/man_wrdapp?sedsize. Grain-size statistics generated by SEDSIZE include:

-percentage of gravel $(>2 \mathrm{~mm})$ by weight, -percentage of sand $(0.063-2 \mathrm{~mm})$ by weight, -percentage of silt $(0.004-0.063 \mathrm{~mm})$ by weight, -percentage of clay $(<0.004 \mathrm{~mm})$ by weight, -percentage of mud (combined silt and clay) by weight, -various ratios of the grain-size classes described above, and -statistical measures of the grain-size distributions made by using techniques suggested by Folk and Ward (1957), Inman (1952), and Trask (1932).

\section{Appendix 2 - Sediment grain-size distribution data from seafloor samples.} (Files available at http://pubs.usgs.gov/of/2012/1083/of2012-1083_appendixes/of2012-1083_appendix_2/)

Grain-size distribtion data from the seafloor sediment samples are provided in two Excel spreadsheets, one for each sampling phase of this project (pre-project and Phase II). Seafloor samples were not collected during Phase I of the project. The data files are named Appendix_2_Results_PhaseIIt and Appendix_2_Results_PreProject. These files have three worksheets:

Progress - A summary of the completion dates for the laboratory methods utilized for these analyses.

Weights - Raw weights and computed weight-based percentages of the sediment samples from grain-size sieving.

$\boldsymbol{S D S Z}$ - The integrated grain-size distribution results for the sediment samples. Results are presented in the weight-based percentage of sample in 0.25 -phi classes. In addition to these results, a number of sediment statistics were calculated using the USGS SEDSIZE software. Further details about SEDSIZE can be found at http://water.usgs.gov/cgibin/man_wrdapp?sedsize. Grain-size statistics generated by SEDSIZE include:

-percentage of gravel $(>2 \mathrm{~mm})$ by weight, -percentage of sand $(0.063-2 \mathrm{~mm})$ by weight, -percentage of silt $(0.004-0.063 \mathrm{~mm})$ by weight, -percentage of clay $(<0.004 \mathrm{~mm})$ by weight, -percentage of mud (combined silt and clay) by weight, -various ratios of the grain-size classes described above, and -statistical measures of the grain-size distributions made by using techniques suggested by Folk and Ward (1957), Inman (1952), and Trask (1932). In addition, the pre-project file includes the following worksheet:

Sampling_Notes - A summary of the sample dates, sample location (latitude, longitude, relative location on the beach), and the laboratory methods utilized for these analyses. 


\section{Appendix 3 - Sediment grain-size distribution data from beach samples.}

(Files available at

http://pubs.usgs.gov/of/2012/1083/of2012-1083_appendixes/of2012-1083_appendix_3/)

Grain-size distribtion data from the beach-sediment samples obtained during the preproject and Phase II of the project are provided in two workbooks named:

Appendix_3_Results_PhaseII and Appendix_3_Results_PreProject. Both files contain the following worksheets:

Weights - Raw weights and computed weight-based percentages of the sediment samples from grain-size sieving.

SDSZ - The integrated grain-size distribution results for the sediment samples. Results are presented in the weight-based percentage of sample in 0.25 -phi classes. In addition to these results, a number of sediment statistics were calculated using the USGS SEDSIZE software. Further details about SEDSIZE can be found at http://water.usgs.gov/cgibin/man_wrdapp?sedsize. Grain-size statistics generated by SEDSIZE include:

-percentage of gravel ( $>2 \mathrm{~mm}$ ) by weight, -percentage of sand $(0.063-2 \mathrm{~mm})$ by weight, -percentage of silt $(0.004-0.063 \mathrm{~mm})$ by weight, -percentage of clay $(<0.004 \mathrm{~mm})$ by weight, -percentage of mud (combined silt and clay) by weight, -various ratios of the grain-size classes described above, and -statistical measures of the grain-size distributions made by using techniques suggested by Folk and Ward (1957), Inman (1952), and Trask (1932).

In addtion, the pre-project file contains the following worksheet:

Sampling_Notes - A summary of the sample dates, sample locations (latitude, longitude, relative location on the beach), and the laboratory methods utilized for these analyses. The Phase II file contains the following additional worksheets:

Progress - A summary of the completion dates for the laboratory methods utilized for these analyses.

Pit Details - Sample location information, including sample depth and along-trench distance.

\section{Appendix 4 - Suspended-sediment concentration and grain-size distribution data from beach-swash samples.}

(Files available at http://pubs.usgs.gov/of/2012/1083/of2012-1083_appendixes/of2012-1083_appendix_4/)

Suspended-sediment concentration and grain-size distribtion data from the swash-water samples are provided in two workbooks named Appendix_4_Results_PhaseI and Appendix_4_Results_PhaseII. There are two sheets within these files:

Weights - Raw weights and computed weight-based percentages of the suspendedsediment samples from grain-size sieving.

$\boldsymbol{S D S Z}$ - The integrated grain-size distribution results for the fine fractions of the suspended-sediment samples. Results are presented in the weight-based percentage of sample in 0.25 -phi classes. In addition to these results, a number of sediment statistics were calculated using the USGS SEDSIZE software. Further details about SEDSIZE can be found at http://water.usgs.gov/cgi-bin/man_wrdapp?sedsize. Grain-size statistics generated by SEDSIZE include:

-percentage of gravel $(>2 \mathrm{~mm})$ by weight, 
-percentage of sand $(0.063-2 \mathrm{~mm})$ by weight,

-percentage of silt $(0.004-0.063 \mathrm{~mm})$ by weight,

-percentage of clay $(<0.004 \mathrm{~mm})$ by weight,

-percentage of mud (combined silt and clay) by weight,

-various ratios of the grain-size classes described above, and

-statistical measures of the grain-size distributions made by using techniques suggested by Folk and Ward (1957), Inman (1952), and Trask (1932).

\section{Appendix 5 - Conductivity-temperature depth (CTD) and optical turbidity measurements from small vessel water sampling.}

(Files available at http://pubs.usgs.gov/of/2012/1083/of2012-1083_appendixes/of2012-1083_appendix_5/)

The CTD data from both Phase I and II of the Demonstration Project are provided in raw text files (.cnv files). Each file includes all samples from one CTD cast, including the initial samples at the water surface, the downcast, and the upcast. These files are organized by sample date, and each complete sampling of the stations is provided in an unique folder. The folder names have the following format: $C_{T} \boldsymbol{T D}_{-} \boldsymbol{Y Y Y} \boldsymbol{Y}_{-} \boldsymbol{M M}_{-} \boldsymbol{D D}$, where:

$\boldsymbol{Y Y Y Y}$ is the year,

$\boldsymbol{M M}$ is the numerical month, and

DD is the numerical day of the month.

Each file within these folders represents the entire CTD cast for one station. The station name (for example, C08, D14, and Buoy-N) is given in each file name.

The downcast CTD data from Phase II of the Demonstration Project also were depth averaged using a $0.25 \mathrm{~m}$ interval and compiled with station latitude and longitude in structured arrays within Matlab (.mat) files. These depth-averaged data are available in the

Appendix_5_Results_CTD_PhaseII folder. Each file contains a complete sampling of all of the stations, which typically encorporates all of the sampling from a single day. Three files are available for the September 30, 2009, because the stations were sampled three complete times. Within each file the sampling data are stored within a structured array entitled ctdBin that includes the following fields:

name-the original raw data file name, station-coastal sampling station, varlable-the original CTD sample variables recorded, spans-the length of sample record averaged, samp_interval-the depth interval in meters for averaging, mtime-the Matlab time of the beginning of sampling, gtime-the calendar time of the beginning of sampling [year month day hour minute second],

sensors-names of sensors sampled,

latitude-latitude of station in decimal degrees, longitude-longitude of station in decimal degrees, tzone-the time zone of sampling, timeJ-time of sample in Julian days, timeS-time of sample in seconds after the sensor turned on, prdM-average pressure of samples in dbar, depSM-average depth of samples in meters, 
c0S-average conductivity of samples in microSiemens per meter, sal00-average salinity of samples in practical salinity units (psu), tv290C-average temperature of samples in degrees Celsius, density00-average density of of samples in kilograms in cubic meters, v0-average voltage of the tramissometer external sensor (channel \#0), bat-average beam attenuation of the transmissometer sensor in meters ${ }^{-1}$, v2-average voltage of the optical backscatterance external sensor (channel \#3), flag-'NaN' if no data available for averaging, ' 0 ' if adequate data for averaging, scan-average number of the sequential scan since the CTD was turned on, and dep_reg-midpoint of the 0.25 -meter depth averaged bins.

For more information about the .mat file format, please see Mathworks at www.mathworks.com. Note that $\mathbf{N a N}$ within any of these fields represents 'not a number' and is utilized for fields in which no data were recorded or available.

\section{Appendix 6 - Suspended-sediment concentration measurements from small vessel water sampling.}

(Files available at http://pubs.usgs.gov/of/2012/1083/of2012-1083_appendixes/of2012-1083_appendix_6/)

Suspended-sediment concentration data from the coastal surface-water samples are provided in the workbook named Appendix_6_Results. There is one sheet within this file that provides the raw weights and computed weight-based percentages of the suspended-sediment samples from grain-size sieving.

\section{Appendix 7 - Remote-sensing imagery.}

(Files available at http://pubs.usgs.gov/of/2012/1083/of2012-1083_appendixes/of2012-1083_appendix_7/)

Digital data from the remote-sensing images are provided in the Appendix_7_Remote_Sensing_Imagery_PhaseII folder. The raw data files are large, approximately $55 \mathrm{MB}$ for the thermal infrared (TIR) images and $110 \mathrm{MB}$ for the red, green, blue (RGB) images. Because of these large file sizes, smaller TIFF files of these images are provided in the Imagery_Clips folder. These TIFF files are named using the following convention: $\boldsymbol{Y Y Y Y} \boldsymbol{M}_{\mathbf{M}} \boldsymbol{M} \boldsymbol{D} \boldsymbol{D}_{\mathbf{X}} \boldsymbol{X X X}$, where $\boldsymbol{Y Y Y Y}$ is the year, $\boldsymbol{M M}$ is the numeric month, $\boldsymbol{D D}$ is the day of the month, and $\boldsymbol{X} \boldsymbol{X} \boldsymbol{X}$ is the image type (' $\boldsymbol{r} \boldsymbol{g} \boldsymbol{b}$ ' or ' $\boldsymbol{T I R}$ '). Note that two images were collected on September 23, 2009, and these are labeled $\boldsymbol{A}$ and $\boldsymbol{B}$ for the early and late flights, respectively.

Raw data are provided in the Imagery_ALL folder. Before accessing these data, please review the metadata provided for both the RGB data (dmsc_x $\left.x \boldsymbol{x} x \boldsymbol{x} \boldsymbol{x} \boldsymbol{x} \_\boldsymbol{r g} \boldsymbol{r}_{-} \boldsymbol{m e t a d a t a . h t m}\right)$ and the TIR data (tir_xxxxxx_rgb_metadata.htm). These metadata files have complete information about image acquisition and processing. Each individual image has three files: a full resolution TIFF file (.tif), a full resolution raster file (.rrd), and an auxiliary information file associated with the image (.aux). These files are named with the following convention:

$Z_{Z Z} \boldsymbol{M M D D Y}_{-} \boldsymbol{X X X} \boldsymbol{X} \mathbf{Y Y Y}$, where $\boldsymbol{Z Z Z}$ is the sensor type ('dmsc' for the multispectral sensor, ' $i r$ ' for the thermal infrared sensor), $\boldsymbol{M M}$ for the numeric month, $\boldsymbol{D D}$ for the day of the month, $\boldsymbol{Y Y}$ for the last two digits of the year ('09' for 2009), $\boldsymbol{X} \boldsymbol{X X}$ for the image type ('rgb' or 'tir'), and $\boldsymbol{Y Y Y}$ for the file type as noted above. For further information about these images and imagery data, see the metadata. 


\section{Appendix 8 - Oceanographic data.}

(Files available at

http://pubs.usgs.gov/of/2012/1083/of2012-1083_appendixes/of2012-1083_appendix_8/)

The oceanographic data from the tripods and buoys are organized by phase of the

Demonstration Project and mooring ID. All data from a specific mooring are contained with a separate folder. The folder names are the mooring IDs and have the following format:

PPPYYMMM, where

$\boldsymbol{P P P}$ is the project ("TJR" for all),

$\boldsymbol{Y Y}$ is the final two digits of the year ("08" or "09"), and

$\boldsymbol{M M M}$ is the mooring number, where

the first digit is the location ("N" for northern, "C" for central, " $\mathrm{S}$ " for southern), the second digit is the mooring number at that location, and

the third digit denotes the type of mooring (" $\mathrm{T}$ " for benthic tripod, " $\mathrm{S}$ " for surface buoy).

The data are stored in the netCDF format as noted above in this report, and metadata and information about measurement units and sampling intervals are provided in each file.

Information about the netCDF file format can be found in Montgomery and others (2008). File names have the following format: PPPYYMMMNNFF.nc, where

PPPYYMMM is the mooring ID as noted above,

$N N$ is the sequential file number from this mooring (" 01 ", " 02 ", etc. to the total number of files), and

$\boldsymbol{F F}$ is the instrument and data type, including:

"adv2s-cal" for SonTek/YSI ADV-O current measurements and concurrent OBS

and/or transmissometer data,

"aq-cal” for calibrated Nortek AS Aquadopp current meter data,

"aw-cal" for Nortek AWAC current data and concurrent OBS data,

"awWvs-p" for Nortek AWAC directional wave data,

"ls-s" for Sequoia Scientific Inc. LISST-100X data,

"mc" for Seabird microcat CTD,

"nx" for the Falmouth Scientific, Inc. (now part of Teledyne RDI) Non-eXternal

Inductive Cell (NXIC) CTD, and

"wh" for Teledyne RDI ADCP currents. 